\title{
COMPLEX ZONING OF CLINOPYROXENES IN THE LAVAS OF VULSINI, LATIUM, ITALY: EVIDENCE FOR MAGMA MIXING
}

\author{
MICHAEL BARTON ${ }^{1}$, JOHAN C. VAREKAMP ${ }^{2}$ and MANFRED J. VAN BERGEN ${ }^{1}$ \\ ${ }^{1}$ Vening Meinesz Laboratory, Department of Geochemistry, Institute of Earth Sciences, \\ State University of Utrecht, Budapestlaan 4, Postbus 80.021, 3508 TA Utrecht: (The \\ Netherlands) \\ ${ }^{2}$ Department of Geology, Arizona State University, Tempe, AR 85287 (U.S.A.)
}

(Received February 23, 1982; revised and accepted August 4, 1982)

\begin{abstract}
Barton, M., Varekamp, J.C. and Van Bergen, M.J., 1982. Complex zoning of clinopyroxenes in the lavas of Vulsini, Latium, Italy: evidence for magma mixing. J. Volcanol. Geotherm. Res., 14: 361-388.

Microprobe analyses of pyroxene phenocrysts occurring in two tephritic leucitites, two leucite phonolites and one trachyte from Vulsini are reported. Three compositionally distinct types of pyroxene occur in the tephritic leucitites: (a) salite, forming resorbed cores in pyroxene phenocrysts; (b) diopside, forming euhedral-anhedral cores in pyroxene phenocrysts: and (c) pyroxene of intermediate composition to (a) and (b), which occurs as mantels around the phenocryst cores, as separate phenocrysts and as microphenocrysts. The pyroxenes in the leucite phonolites and in the trachyte do not show discontinuous zoning such as that shown by pyroxenes in the tephritic leucitites. The compositional characteristics of the latter are most easily explained by the mixing of two magmas, both tephritic leucitite in composition, one of which was relatively evolved (Fe-rich) and carried salite phenocrysts, the other relatively primitive (Mg-rich) which carried diopside phenocrysts. A review of petrographic and geochemical evidence indicates that magma mixing may have been an important process, in addition to fractional crystallization, at Vulsini and at other central Italian volcanic centres. The implications for theories about the origin of potassium-rich magmas in western Italy are briefly discussed.
\end{abstract}

\section{INTRODUCTION}

Despite the controversy surrounding the origin of the potassium-rich alkaline rocks of central Italy, it is generally accepted that much of the chemical variation displayed by the lavas in this region is the result of low-pressure fractional crystallization (Cundari and Le Maitre, 1970; Appleton, 1972; Cundari and Mattias, 1974; Cundari, 1979; Varekamp, 1979; Barberi and Leoni, 1980). Other processes that could have operated in the magma chambers underlying the Italian volcanoes include assimilation of crustal rocks and magma mixing. The importance of contamination in the genesis of the potassium-rich magmas in central Italy is currently being debated 
(Savelli, 1967; Appleton, 1972; Barbieri et al., 1975; Turi and Taylor, 1976; Cundari, 1979; Hawkesworth and Vollmer, 1979; Taylor et al., 1979; Vollmer and Hawkesworth, 1980), but there is petrographic evidence that assimilation occurred at least on a small scale at some volcanic centres, e.g., Vulsini (Varekamp, 1979). Magma mixing has recently been shown to be an important process in the evolution of mid-ocean ridge basalts (Donaldson and Brown, 1977; Dungan and Rhodes, 1978; Rhodes et al., 1979; Shibata et al., 1979; Walker et al., 1979) and calc-alkaline magmas (Anderson, 1976; Sakuyama, 1979; Luhr and Carmichael, 1980) and ususally results from the periodic injection of fresh magma into a magma chamber which contains the differentiation products of previous batches of primitive or parental magma (O'Hara, 1977). This process undoubtedly plays a role in the evolution of some mafic alkaline magmas (see Brooks and Printzlau, 1978), especially in those regions where volcanic activity is episodic and where magmas are stored in reservoirs fairly close to the surface - e.g., in central Italy.

In a hybrid magma resulting from assimilation or magma mixing, the phenocrysts may show textural evidence of disequilibrium with the host liquid and may have compositions which differ from those expected to result from normal crystal-liquid equilibria for that bulk composition (Eichelberger, 1975; Rhodes et al., 1979; Sakuyama, 1979; Luhr and Carmichael, 1980; Barton and Van Bergen, 1981). Disequilibrium phenocryst assemblages are relatively common in the potassium-rich lavas of central Italy. In particular, green, salitic pyroxene phenocrysts occur together with colourless or lightgreen coloured pyroxene phenocrysts in lavas from many volcanic centres. It has been suggested that the presence of such compositionally distinct diopsidic and salitic phenocrysts in mafic alkaline lavas is the result of the mixing of two discrete magma batches (Thompson, 1977; Brooks and Printzlau, 1978). However, Barton and Van Bergen (1981) have shown that the presence of green salitic pyroxenes in potassic lavas from the Leucite Hills, Wyoming, and the Toro-Ankole region, Uganda, is due to the disaggregation of xenoliths of probable upper mantle material and not to magma mixing. We therefore undertook a detailed study of the pyroxene phenocrysts in five lavas from Vulsini in an attempt to determine whether their com. positions and zoning patterns provide evidence for magma mixing.

\section{GENERAL GEOLOGY OF THE VULSINI AREA}

Vulsini is the most northerly of the Roman Province volcanic centres (Fig. 1) and is also the largest, covering an area of some $2300 \mathrm{~km}^{2}$. The geology and petrology of the volcanic complex have been described most recently by Varekamp $(1979,1980)$, who divided it into three major zones (Fig. 2): the Bolsena-Orvieto zone (to the NE), the Montefiascone zone (to the SE) and the Latera zone (to the W). Six major phases of volcanic activity can be recognized and these are summarized in Table I. K/Ar dating 


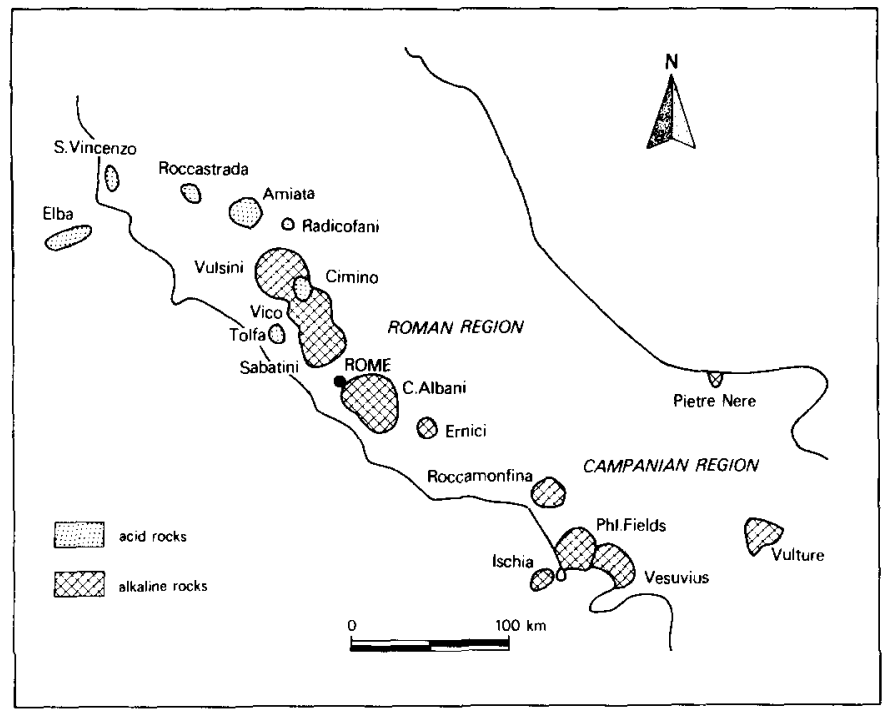

Fig. 1. Major Pliocene-Quaternary volcanic centres in central and south Italy.

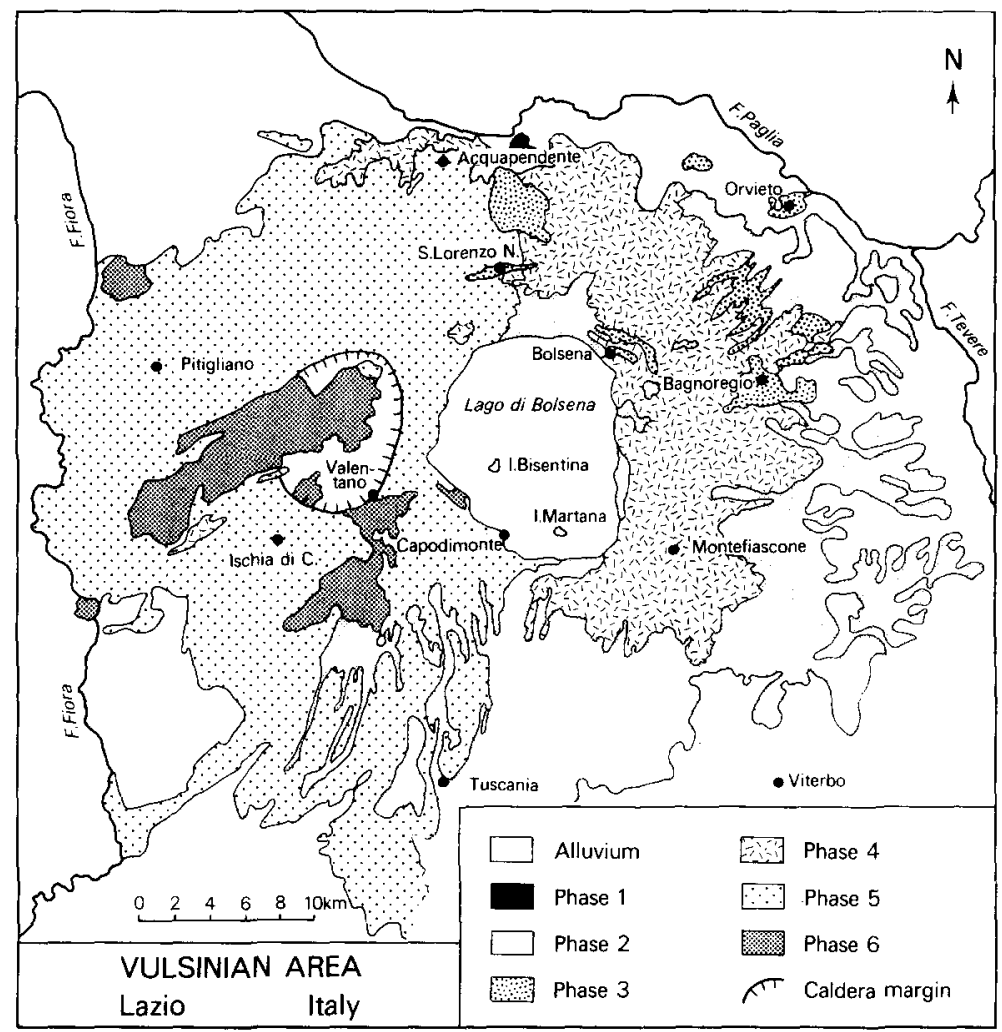

Fig. 2. Simplified volcanological map of the Vulsini area (after Varekamp, 1979). 


\section{TABLE I}

Characteristics of the phases of volcanic activity

\begin{tabular}{llll}
\hline Phase & Age (m.y.) & Type of activity & Main rock types \\
\hline 6 & $0.055-$ recent & $\begin{array}{l}\text { Cinders, ashes, phreatomagmatic eruptions. } \\
\text { Strombolian and Surtseyan activity. Erup- } \\
\text { tion of lava flows from small, local centres }\end{array}$ & $\begin{array}{l}\text { Trachybasalt, latite, } \\
\text { leucitite }\end{array}$ \\
5 & $0.25-0.055$ & $\begin{array}{l}\text { Ash flows, mud flows, phreatomagmatic } \\
\text { tuffs, pumice-fall deposits, base-surge } \\
\text { deposits }\end{array}$ & Trachyte, latite \\
& $\begin{array}{l}\text { Tuffs, cinders, lava flows from numerous } \\
\text { small centres. One extensive lava plateau } \\
\text { occurs in the Bolsena-Orvieto zone }\end{array}$ & $\begin{array}{l}\text { Basanite, leucitite, } \\
\text { tephrite, phonolite }\end{array}$ \\
3 & $0.35-0.25$ & $\begin{array}{l}\text { Lava flows, ash flows, mudflows } \\
\text { Layered tuffs, ash flows, lava flows }\end{array}$ & $\begin{array}{l}\text { Latite, trachyte } \\
\text { Basanite, leucitite, } \\
\text { tephrite, phonolite }\end{array}$ \\
2 & $0.40-0.35-0.40$ & Lava flows, ash flows & $\begin{array}{l}\text { Trachybasalt, latite, } \\
\text { trachyte }\end{array}$ \\
\hline
\end{tabular}

methods and detailed volcanological studies indicate an age of $\sim 0.92 \mathrm{~m} . \mathrm{y}$. for Phase 1 and a sub-recent age for the end of Phase 6.

The volcanic products include lava flows, ash flows, mud flows, phreatomagmatic tuffs and cinders which were mainly erupted from small centres scattered throughout the district. Voluminous ash flows were erupted from the large Latera volcano and from a centre now submerged in the Bolsena lake. Towards the end of Phase 5, the summit of the Latera volcano collapsed to form a caldera (Fig. 2). Subsidence occurred throughout much of the volcanic history and was controlled by NW-SE, N-S and E-W trending faults which produced graben-type structures with considerable vertical displacement. Most of the volcanic centres appear to have been located on these faults, and eruption of basic, potassic magmas followed periods of strong subsidence (Varekamp, 1981).

Appleton (1972) has divided the lavas of the Roman Province into two major series: (1) the high-potassium series (HKS) which includes the rock types leucite basanite, olivine leucitite, leucitite, tephritic-leucitite, leucite tephrite, phonolitic-leucite tephrite, tephritic-leucite phonolite and leucite phonolite; and (2) the low-potassium series (LKS) which includes trachybasalt, latite and trachyte. The rocks of the HKS are all undersaturated with respect to silica whereas the rocks of the LKS vary from marginally undersaturated to oversaturated with respect to silica. From Table I it is evident that volcanic acitivity in the Vulsini district was largely cyclic, members of the LKS being eurpted in Phases 1, 3 and 5 and members of the HKS being erupted in Phases 2 and 4. Members of both series were erupted in Phase 6.

Petrological studies (Brotzu et al., 1973; Varekamp, 1979) and least- 
squares mixing calculations using major element analyses (Varekamp, 1979) indicate that the series tephritic leucitite-leucite phonolite can be explained by fractional crystallization involving removal of the observed phenocryst phases (see below). This evolutionary trend is similar to that deduced by Appleton (1972) for the HKS of Roccamonfina and by Cundari (1979) for the Sabatini lavas. The relationship of the most mafic lavas to other members of the HKS at Vulsini is unknown; least-squares mixing calculations using a leucite basanite as a parental magma for the tephritic leucitites proved unsuccessful. Varekamp (1979) has estimated that the HKS lavas evolved at a total pressure of $1-2 \mathrm{kbar}$. The results of 1 -atmosphere melting experiments on a Vulsini tephritic leucitite (Trigila, 1969) and the normative di:lc ratios of Vulsini leucitites (Thompson, 1977) also suggest that these lavas have evolved at low pressures.

The members of the LKS are probably also related to one another by fractional crystallization (cf. Appleton, 1972; Ghiara and Lirer, 1977), but this has not been confirmed using major element, least-squares calculations. The relationship of the HKS and LKS at Vulsini is unknown, but these two series could be related by high-pressure processes such as fractional crystallization or melting (e.g., Appleton, 1972).

\section{SUMMARY OF PETROGRAPHY}

The petrographic characteristics of the HKS lavas are summarized in Table II. The main phenocrystal and microphenocrystal minerals are clinopyroxene, leucite, olivine, plagioclase, sanidine, magnetite and biotite. Olivine is present

TABLE II

Summary of the petrography of the HKS lavas

\begin{tabular}{lllllll}
\hline & Basanite & Leucitite & $\begin{array}{l}\text { Tephritic- } \\
\text { leucitite }\end{array}$ & $\begin{array}{l}\text { Leucite } \\
\text { tephrite }\end{array}$ & $\begin{array}{l}\text { Phonolitic- } \\
\text { leucite } \\
\text { tephrite }\end{array}$ & $\begin{array}{l}\text { Leucite } \\
\text { phonolite }\end{array}$ \\
\hline Ol & PG & (P) $(G)$ & (G) & & & \\
Cpx & PG & PG & PG & PG & PG & PG \\
Lc & PG & PG & PG & PG & PG & PG \\
Plag & PG & & G & PG & PG & PG \\
San & & & & & G & PG \\
Fe-ore & (P) G & (P) G & (P) G & (P) G & (P) G & (P) G \\
Bi* & (G) & (G) & (G) & (G) & (P) $(G)$ & (P) (G) \\
Hy & & & & & & (P) $(G)$
\end{tabular}

*Mostly resorbed and represented by pseudomorphs of Fe-ore and unidentified minerals. Abbreviations: $\mathrm{OI}=$ olivine $; \mathrm{Cpx}=$ clinopyroxene $; \mathrm{Lc}=$ leucite Plag = plagioclase $; \mathrm{San}=$ sanidine $; \mathrm{Fe}$-ore $=$ opaque oxide $; \mathrm{Bi}=$ biotite $; \mathrm{Hy}=$ haüyne $\mathrm{P}=$ phenocryst $; \mathrm{G}=$ groundmass; ( ) rare. 
only in the more mafic rocks (basanites-tephritic leucitites) whereas sanidine and, rarely, haüyne, are found as phenocrysts only in the phonolites. Biotite phenocrysts are usually strongly resorbed and are often represented by pseudomorphs consisting mainly of magnetite. Nepheline is a fairly common groundmass constituent whereas an olive-brown amphibole occassionally occurs in the groundmass of some tephritic leucitites and leucite phonolites.

The LKS lavas have not been studied in detail. The main phenocrystal and microphenocrystal phases are olivine, clinopyroxene, plagioclase, sanidine, biotite and magnetite. Some of the trachytes contain resorbed quartz which is probably xenocrystal in origin.

\section{SAMPLES SELECTED FOR STUDY}

Green, salitic pyroxenes occur in the HKS lavas of Phases 2 and 4, but they are especially common in the Phase 4 lavas of the Bolsena-Orvieto zone. These range from leucitites to phonolitic-leucite tephrites and salitic pyroxenes are observed in all lava types. Two samples of tephritic leucitite (samples TL 820 and TL 977), both from lava flows along the Via Cassia, south of Bolsena, were selected for detailed study.

In order to compare the composition of the salitic pyroxene in the tephritic leucitites with the compositions of pyroxenes in the more evolved Vulsini lavas, two samples of leucite phonolite and one of trachyte were also studied. One of the leucite phonolites (LP 612) is from a Phase 4 lava flow just to the west of Aquapendente in the Latera zone whereas the other (LP 423) is from a Phase 2 lava flow near Sugano in the Bolsena-Orvieto zone. The trachyte (T 885) was collected from a Phase 3 lava flow to the north of San Lorenzo Nuovo, which is also in the Bolsena-Orvieto zone.

Chemical analyses and CIPW norms of the five lavas are given in Table III. The tephritic leucitites and the leucite phonolites are nepheline normative whereas the LKS trachyte is quartz normative. It is noteworthy that the two tephritic leucites have significantly different $\mathrm{Mg} /\left(\mathrm{Mg}+\Sigma \mathrm{Fe}^{2+}\right)$ ratios $(0.57$ and 0.45$)$ whereas the two leucite phonolites have similar $\mathrm{Mg} /(\mathrm{Mg}+$ $\left.\Sigma \mathrm{Fe}^{2+}\right)$ ratios $(0.29$ and 0.28$)$.

\section{COMPOSITION AND ZONING OF PYROXENES}

Chemical analyses were obtained at the University of Manchester using a Cambridge Geoscan Microanalyser fitted with a Link Systems Ltd. energydispersive system. Operating conditions were: $15 \mathrm{kV}$ accelerating voltage, 3-4 nA sample current and 100 seconds counting time. Analyses were corrected for deadtime, background, atomic number, absorption and fluorescence.

Representative analyses are presented in Tables IV and VI. Ferric iron contents were calculated by assuming that the pyroxenes are stoichiometric with the sum of the cations equal to 4 on the basis of 6 oxygens. Mineral 


\section{TABLE III}

Chemical analyses and CIPW norms of the lavas studied

\begin{tabular}{|c|c|c|c|c|c|}
\hline Sample & TL 820 & TL 977 & LP 612 & LP 423 & T 885 \\
\hline \multicolumn{6}{|c|}{ Chemical analyses } \\
\hline $\mathrm{SiO}_{2}$ & 46.82 & 46.34 & 54.87 & 53.64 & 60.88 \\
\hline $\mathrm{TiO}_{2}$ & 0.74 & 0.76 & 0.50 & 0.51 & 0.55 \\
\hline $\mathrm{ZrO}_{2}$ & 0.05 & 0.06 & 0.08 & 0.10 & 0.06 \\
\hline $\mathrm{Al}_{2} \mathrm{O}_{3}$ & 16.21 & 18.06 & 20.23 & 19.89 & 16.28 \\
\hline $\mathrm{Fe}_{2} \mathrm{O}_{3}$ & 5.54 & 3.80 & 2.06 & 3.14 & 1.40 \\
\hline $\mathrm{FeO}$ & 2.34 & 4.06 & 1.66 & 0.99 & 3.58 \\
\hline $\mathrm{MnO}$ & 0.15 & 0.17 & 0.15 & 0.15 & 0.11 \\
\hline $\mathrm{MgO}$ & 5.35 & 3.38 & 0.80 & 0.83 & 0.99 \\
\hline $\mathrm{CaO}$ & 11.19 & 9.66 & 3.29 & 3.59 & 0.80 \\
\hline $\mathrm{SrO}$ & 0.21 & 0.28 & 0.20 & 0.28 & 0.08 \\
\hline $\mathrm{BaO}$ & 0.18 & 0.22 & 0.26 & 0.30 & 0.11 \\
\hline $\mathrm{Na}_{2} \mathrm{O}$ & 1.85 & 2.40 & 4.02 & 2.89 & 2.94 \\
\hline $\mathrm{K}_{2} \mathrm{O}$ & 7.23 & 8.44 & 10.85 & 9.64 & 7.71 \\
\hline $\mathrm{P}_{2} \mathrm{O}_{5}$ & 0.46 & 0.50 & 0.19 & 0.19 & 0.30 \\
\hline $\mathrm{LOI}^{\mathrm{a}}$ & 2.25 & 1.32 & 0.73 & 2.95 & 2.80 \\
\hline Total & $\overline{100.57}$ & $\overline{99.45}$ & $\overline{99.89}$ & 99.09 & 98.59 \\
\hline$\frac{M g}{(M g+\Sigma}$ & b $\quad 0.57$ & 0.45 & 0.29 & 0.28 & 0.27 \\
\hline \multicolumn{6}{|c|}{$C I P W$ norms } \\
\hline $\mathrm{Q}$ & & & & & 6.26 \\
\hline $\mathrm{Z}$ & 0.07 & 0.09 & 0.12 & 0.15 & 0.09 \\
\hline or & 10.23 & 3.84 & 62.19 & 57.85 & 46.14 \\
\hline$a b$ & - & - & - & 7.77 & 25.19 \\
\hline an & 14.50 & 13.80 & 5.05 & 13.06 & 8.62 \\
\hline lc & 25.37 & 36.43 & 1.67 & - & - \\
\hline ne & 8.45 & 11.09 & 18.49 & 9.24 & - \\
\hline wo & 15.93 & 13.21 & 4.41 & 1.81 & 1.53 \\
\hline en & 13.28 & 8.49 & 2.00 & 1.56 & 2.50 \\
\hline fs & - & 3.41 & 0.82 & - & 4.77 \\
\hline fo & - & - & - & 0.38 & - \\
\hline $\mathrm{mt}$ & 5.87 & 5.56 & 3.00 & 2.24 & 2.06 \\
\hline $\mathrm{hm}$ & 1.48 & - & - & 1.65 & - \\
\hline il & 1.40 & 1.46 & 0.95 & 0.98 & 1.06 \\
\hline op & 1.09 & 1.19 & 0.45 & 0.46 & 0.72 \\
\hline
\end{tabular}

${ }^{a}$ Loss on ignition.

${ }^{\mathrm{b}}$ Total iron as $\mathrm{Fe}^{2+}$.

Analyses obtained in the department of Geochemistry, Utrecht, using conventional XRF, AAS and wet chemical techniques. 


\section{TABLE IV}

Representative analyses and formulae of pyroxenes in the tephritic leucitites

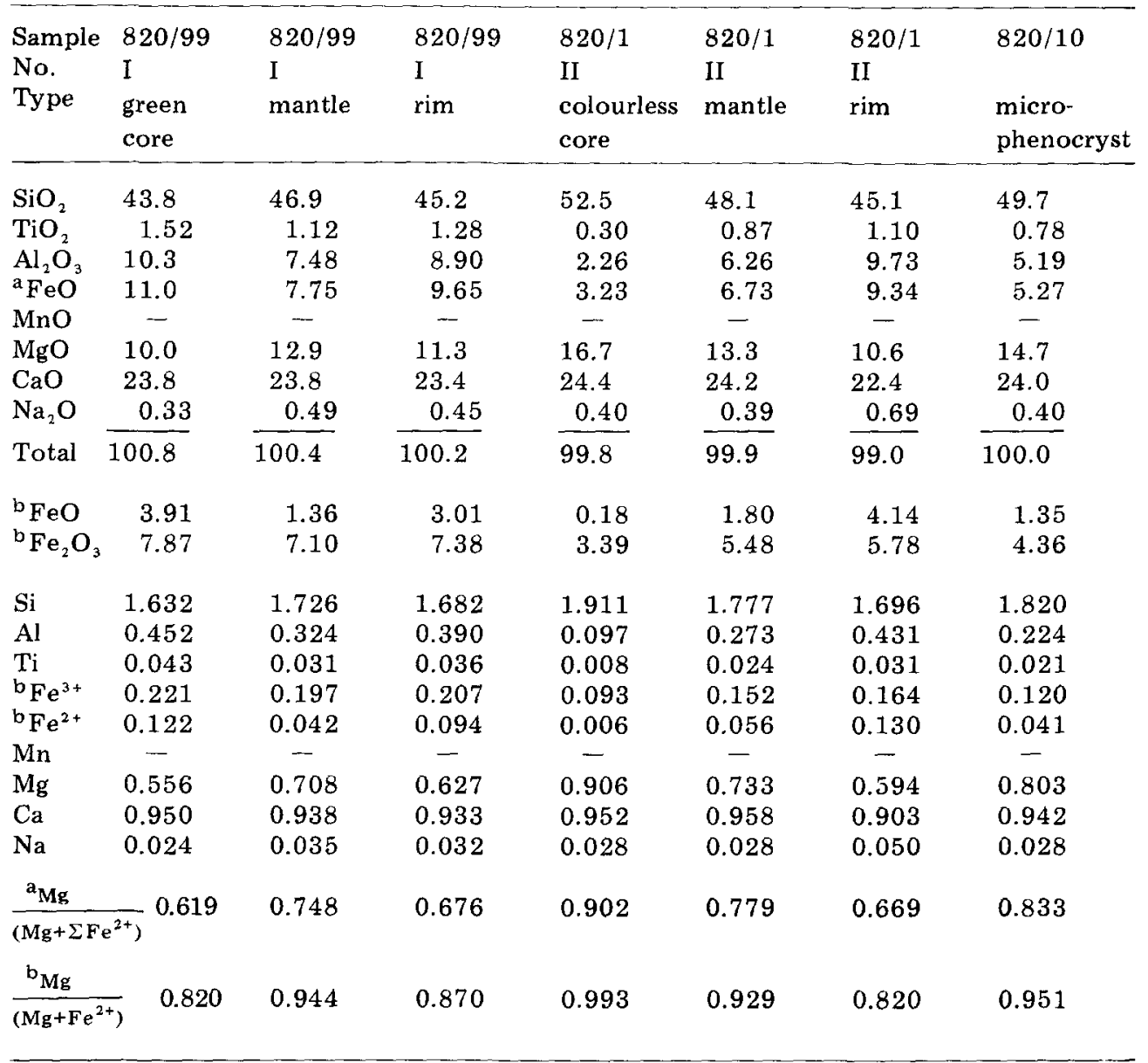

$-=$ below limit of detection. ${ }^{\text {a }} \mathrm{Total}$ iron as $\mathrm{FeO}$ or $\mathrm{Fe}^{2+} \cdot{ }^{\mathrm{b}}$ Calculated assuming $\Sigma$ cations $=$ 4 on the basis of 6 oxygen atoms.

formulae with total iron calculated as $\mathrm{Fe}^{2+}$ were used when plotting the diagrams.

\section{General chemical characteristics}

The pyroxenes in the Vulsini HKS lavas are compositionally similar to pyroxenes in potassium-rich alkaline lavas from other centres in central Italy (Thompson, 1972; Rahman, 1975; Cundari, 1975, 1979; Barton, 1979). They range in composition from diopsides to salites and plot close to or 


\begin{tabular}{|c|c|c|c|c|c|c|c|}
\hline $\begin{array}{l}977 / 1 \\
\text { I } \\
\text { green } \\
\text { core }\end{array}$ & $\begin{array}{l}977 / 1 \\
\text { I } \\
\text { mantle }\end{array}$ & $\begin{array}{l}977 / 1 \\
\text { I } \\
\operatorname{rim}\end{array}$ & $\begin{array}{l}977 / 3 \\
\text { II } \\
\text { colourless } \\
\text { core }\end{array}$ & $\begin{array}{l}977 / 3 \\
\text { II } \\
\text { mantle }\end{array}$ & $\begin{array}{l}977 / 3 \\
\text { II } \\
\text { rim }\end{array}$ & $\begin{array}{l}977 / 14 \\
\text { III } \\
\text { pale-green } \\
\text { phenocryst }\end{array}$ & $\begin{array}{l}977 / 21 \\
\text { micro- } \\
\text { t phenocr. }\end{array}$ \\
\hline 39.2 & 45.5 & 43.3 & 52.5 & 45.7 & 42.4 & 45.0 & 45.1 \\
\hline 1.97 & 1.52 & 1.51 & 0.34 & 1.20 & 1.57 & 1.14 & 1.64 \\
\hline 12.6 & 8.71 & 7.59 & 2.31 & 8.38 & 9.09 & 9.21 & 8.73 \\
\hline 14.6 & 10.8 & 16.3 & 3.02 & 11.1 & 14.9 & 9.37 & 9.31 \\
\hline 0.37 & 0.27 & 0.87 & - & - & 0.56 & - & - \\
\hline 7.11 & 9.85 & 6.90 & 16.8 & 9.77 & 7.50 & 10.6 & 11.6 \\
\hline 23.1 & 23.4 & 22.7 & 24.1 & 23.7 & 22.6 & 24.6 & 23.9 \\
\hline 0.33 & 0.53 & 0.80 & 0.39 & 0.48 & 0.68 & - & - \\
\hline 99.3 & 100.6 & 100.0 & 99.5 & 100.3 & 99.3 & 99.9 & 100.3 \\
\hline 4.47 & 5.52 & 7.16 & 0.47 & 5.73 & 6.07 & 4.44 & 4.12 \\
\hline 11.3 & 5.87 & 10.2 & 2.84 & 5.96 & 9.81 & 5.48 & 5.77 \\
\hline 1.507 & 1.702 & 1.667 & 1.916 & 1.714 & 1.632 & 1.687 & 1.681 \\
\hline 0.571 & 0.384 & 0.344 & 0.099 & 0.370 & 0.412 & 0.407 & 0.384 \\
\hline 0.057 & 0.043 & 0.044 & 0.009 & 0.034 & 0.045 & 0.032 & 0.046 \\
\hline 0.326 & 0.165 & 0.294 & 0.078 & 0.168 & 0.284 & 0.155 & 0.162 \\
\hline 0.144 & 0.173 & 0.231 & 0.014 & 0.180 & 0.195 & 0.139 & 0.129 \\
\hline 0.012 & 0.009 & 0.028 & - & - & 0.018 & - & - \\
\hline 0.408 & 0.549 & 0.396 & 0.914 & 0.546 & 0.430 & 0.592 & 0.645 \\
\hline 0.952 & 0.938 & 0.936 & 0.942 & 0.952 & 0.932 & 0.988 & 0.955 \\
\hline 0.025 & 0.038 & 0.060 & 0.028 & 0.035 & 0.051 & - & - \\
\hline 0.464 & 0.620 & 0.430 & 0.909 & 0.611 & 0.473 & 0.669 & 0.690 \\
\hline 0.739 & 0.760 & 0.632 & 0.985 & 0.752 & 0.688 & 0.810 & 0.833 \\
\hline
\end{tabular}

above the Di-Hd join in the conventional pyroxene quadrilateral (Fig. 3a,b) as a result of high contents of non-quadrilateral components (e.g., Al-bearing end members). All of these pyroxenes contain more than sufficient $\mathrm{Al}$ to balance Si deficiencies in the tetrahedral sites (Fig. 4a) and, because Al:Ti $\geqslant 6: 1$ and $\mathrm{Na}$ shows very poor correlation with $\mathrm{Al}$, it may be inferred that tschermaks components $\left(\mathrm{CaR}^{3+} \mathrm{R}^{3+} \mathrm{SiO}_{6}\right)$ are important constituents of these pyroxenes. For ideal substitution of the type $\mathrm{Mg}^{2+}+\mathrm{Si}^{4+} \leftrightharpoons \mathrm{Al}^{3+}+\mathrm{Al}^{3+}$, there must be twice as much $\mathrm{Al}$ as there are Si deficiencies in the tetrahedral sites $(\mathrm{Al}=2[2-\mathrm{Si}])$, which is clearly not so in the case of the Vulsini pyroxenes 


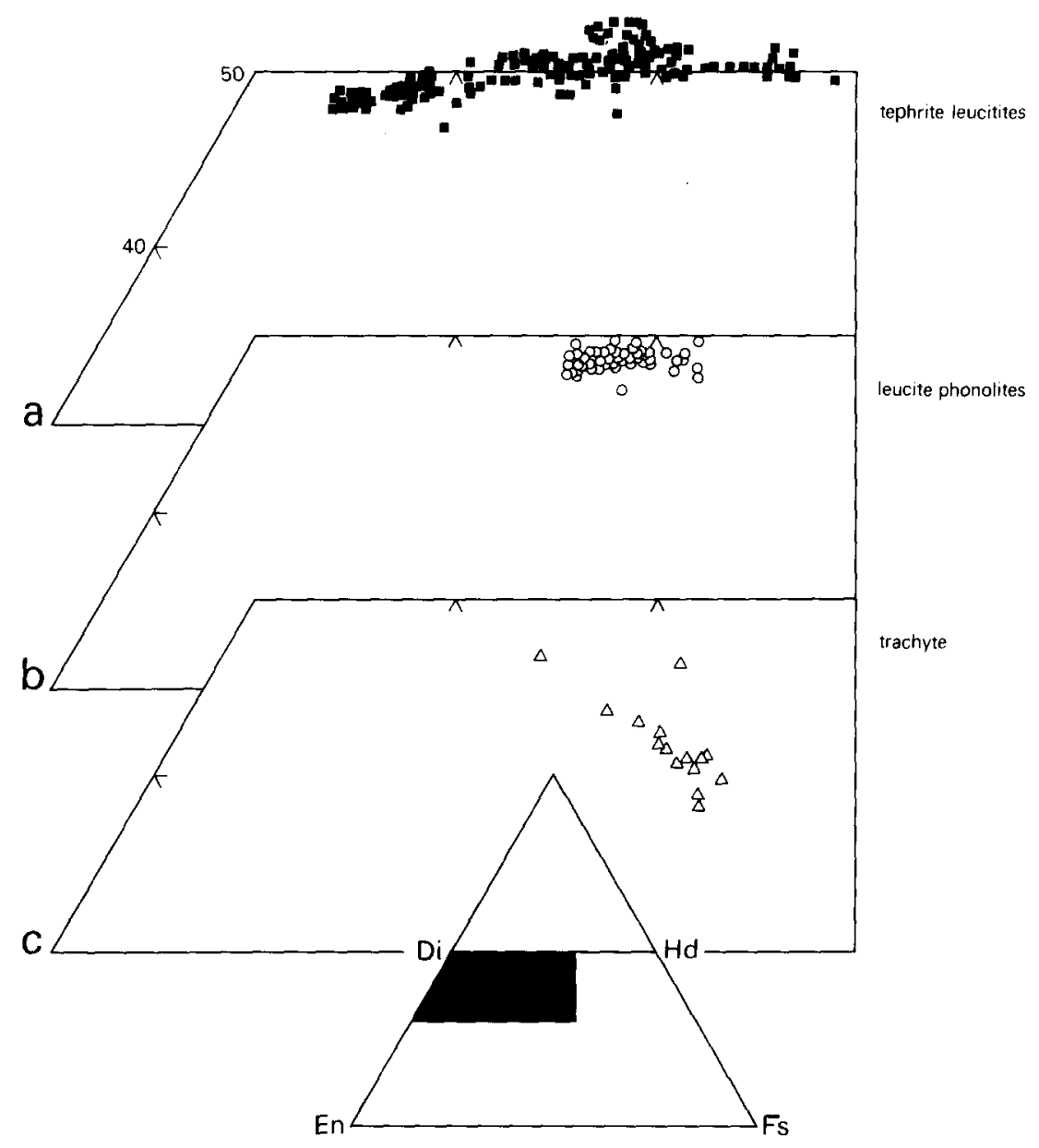

Fig. 3. Clinopyroxene compositions plotted in the conventional $\mathrm{Ca}-\mathrm{Mg}-\mathrm{Fe}+\mathrm{Mn}$ diagram. a. Pyroxenes from the tephritic leucitites. b. Pyroxenes from the leucite phonolites.

c. Pyroxenes from the trachyte.

(Fig. 4a), indicating that ferri-tschermaks components $\left(\mathrm{CaFe}^{3+} \mathrm{AlSiO}_{6}, \mathrm{CaFe}^{3+}\right.$ $\mathrm{Fe}^{3+} \mathrm{SiO}_{6}$ ) are important in addition to $\mathrm{CaAlAlSiO}_{6}$. This is consistent with the high calculated ferric iron contents of these pyroxenes and with the positive correlation between $\mathrm{Al}$ and calculated $\mathrm{Fe}^{3+}$. The low $\mathrm{Na}$ contents indicate that pyroxenes in the Vulsini HKS lavas are poor in acmite, as are pyroxenes in other potassium-rich lavas from central Italy (Barton, 1979).

The pyroxenes in the trachyte are mostly augites (a few plot in the salite field) and plot well below the Di-Hd join (Fig. 3c), as would be expected for pyroxenes from a quartz-normative lava. However, these pyroxenes are similar to those in the HKS lavas inasmuch as $\mathrm{Al}>$ (2-Si) (Fig. 4b), $\mathrm{Al}: \mathrm{Ti} \geqslant 6: 1$ and $\mathrm{Na}$ shows no correlation with $\mathrm{Al}$. The trachyte pyroxenes 

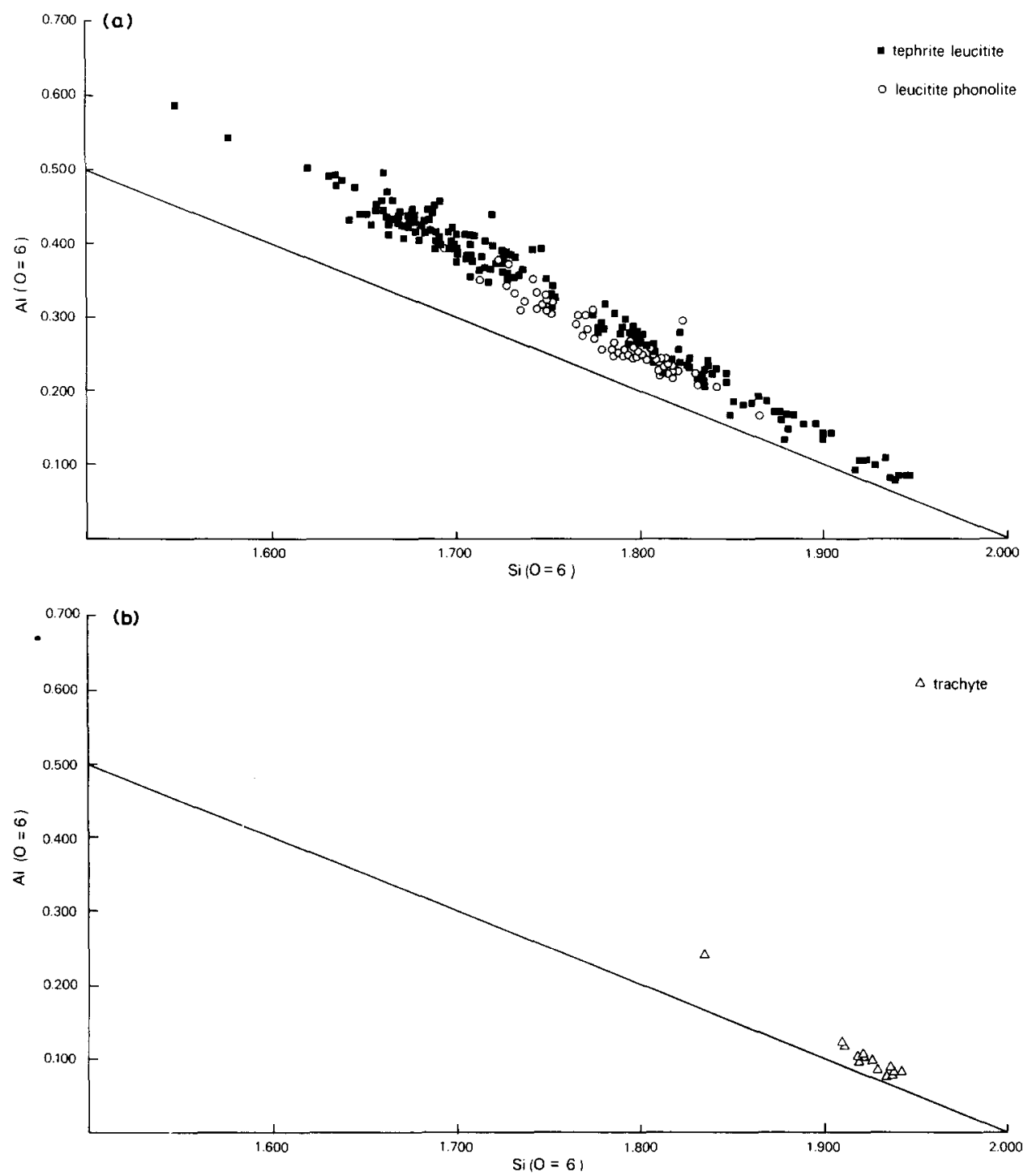

Fig. 4. Aluminium contents plotted against silicon contents of the pyroxenes. a. Pyroxenes from the tephritic leucitites and leucite phonolites. b. Pyroxenes from the trachyte.

are relatively poor in $\mathrm{NaFe}^{3+} \mathrm{Si}_{2} \mathrm{O}_{6}$ and CaTiAlAlO 6 , the most important non-quadrilateral components being $\mathrm{CaAlAlSiO}_{6}, \mathrm{CaFe}^{3+} \mathrm{AlSiO}_{6}$ and, possibly, $\mathrm{CaFe}^{3+} \mathrm{Fe}^{3+} \mathrm{SiO}_{6}$.

Zoning of pyroxenes in the tephritic leucitites

The tephritic leucitites contain up to three distinct types of pyroxene phenocryst (summarized in Table V) hereafter referred to as Type I, Type II 
TABLE V

Summary of petrographic characteristics of pyroxene phenocrysts in the studied lavas

\begin{tabular}{|c|c|c|c|}
\hline Sample No. & $\begin{array}{l}\text { Phenocryst } \\
\text { type }\end{array}$ & Colour and zoning & \\
\hline TL 820 & $\begin{array}{l}\text { Type I } \\
\text { Type II }\end{array}$ & $\begin{array}{l}\text { a) Medium green core, colourless mantle, } \\
\text { pale green rim. } \\
\text { b) Colourless core, pale green rim. }\end{array}$ & $\begin{array}{l}\text { oscillatory } \\
\text { sector, } \\
\text { concentric }\end{array}$ \\
\hline TL 977 & $\begin{array}{l}\text { Type I } \\
\text { Type II } \\
\text { Type III }\end{array}$ & $\begin{array}{l}\text { a) Medium green core, pale green mantle, } \\
\text { dark green rim. } \\
\text { b) Colourless core, pale green mantle, } \\
\text { dark green rim. } \\
\text { c) Pale green, dark green rim }\end{array}$ & $\begin{array}{l}\text { oscillatory } \\
\text { sector, } \\
\text { concentric }\end{array}$ \\
\hline LP 612 & - & Medium green & $\begin{array}{l}\text { oscillatory } \\
\text { sector, } \\
\text { concentric }\end{array}$ \\
\hline LP 423 & - & Medium green & $\begin{array}{l}\text { oscillatory } \\
\text { sector, } \\
\text { concentric }\end{array}$ \\
\hline T 885 & - & Pale green. Usually rimmed by opaques & \\
\hline
\end{tabular}

Abbreviations: $T L=$ tephritic leucitite $\mathrm{LP}=$ leucite phonolite $\mathrm{T}=$ trachy te.

and Type III. Type I is characterized by the presence of a medium-green, pleochroic (pale green-yellow green-grass green) core, Type II has a colourless core and Type III is pale green in colour and is faintly pleochroic.

The cores of Type I phenocrysts are variable in size, have irregular, embayed outlines, which suggests resorption, and, when fresh, usually contain inclusions of magnetite (Fig. 5a,b). In some cases the cores are almost completely replaced by opaques and unidentified minerals. In TL 820 the cores are surrounded successively by a colourless mantle and a pale-green rim whereas in TL 977 the mantles are pale green and the rims are dark green in colour. The boundaries between the cores, mantles and rims are always optically sharp.

The Type II phenocrysts in TL 820 differ from those in TL 977. In the former, the colourless cores are euhedral and are surrounded by a pale-green rim whereas in the latter the cores are anhedral and are surrounded by a pale-green mantle and by a thin, dark-green, strongly pleochroic rim (Fig. 5c).

Type III pyroxene phenocrysts are found only in TL 977 and are mostly uniform in colour except for the rims which are dark green and strongly pleochroic. Occasionally, however, yellow-green bands, $>20 \mu \mathrm{m}$ wide, are observed in these phenocrysts (Fig. 5d).

Each of the phenocryst types described above may show oscillatory, sector and concentric zoning (Fig. 5e). In Type I and II phenocrysts sector zoning is always present either in the core or in the mantle - it never cuts the core/mantle boundary. 

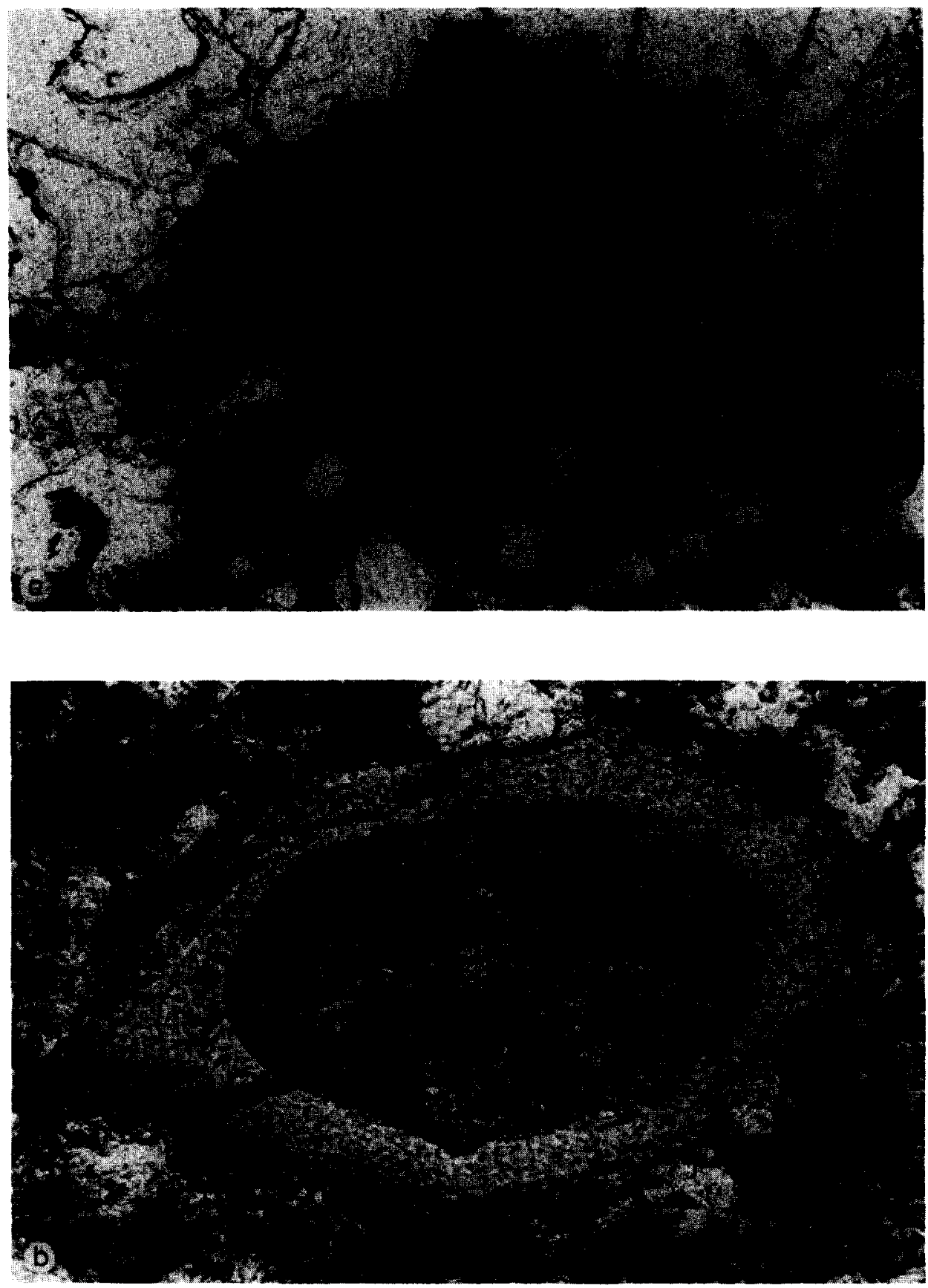

Fig. 5a. Type I phenocryst in TL 977 with anhedral green core. Width of field $1.6 \mathrm{~mm}$. b. Type I phenocryst in TL 977 with strongly resorbed green core and inclusions of magnetite. Width of field $1 \mathrm{~mm}$. 

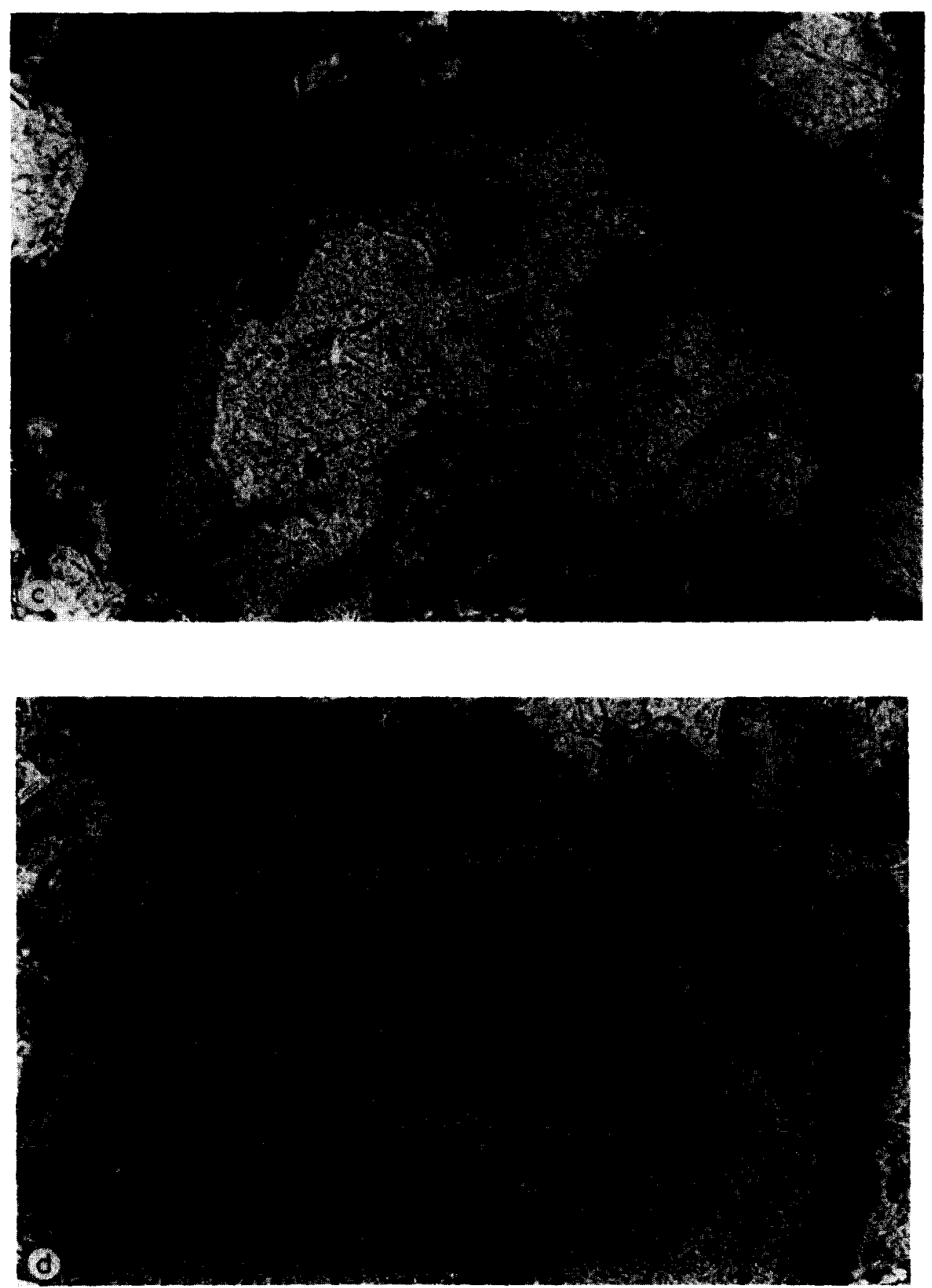

Fig. 5c. Type II phenocryst in TL 977 with anhedral colourless core. Width of field $1 \mathrm{~mm}$. d. Type III phenocryst in TL 977 showing light coloured band. Width of field $1 \mathrm{~mm}$. 

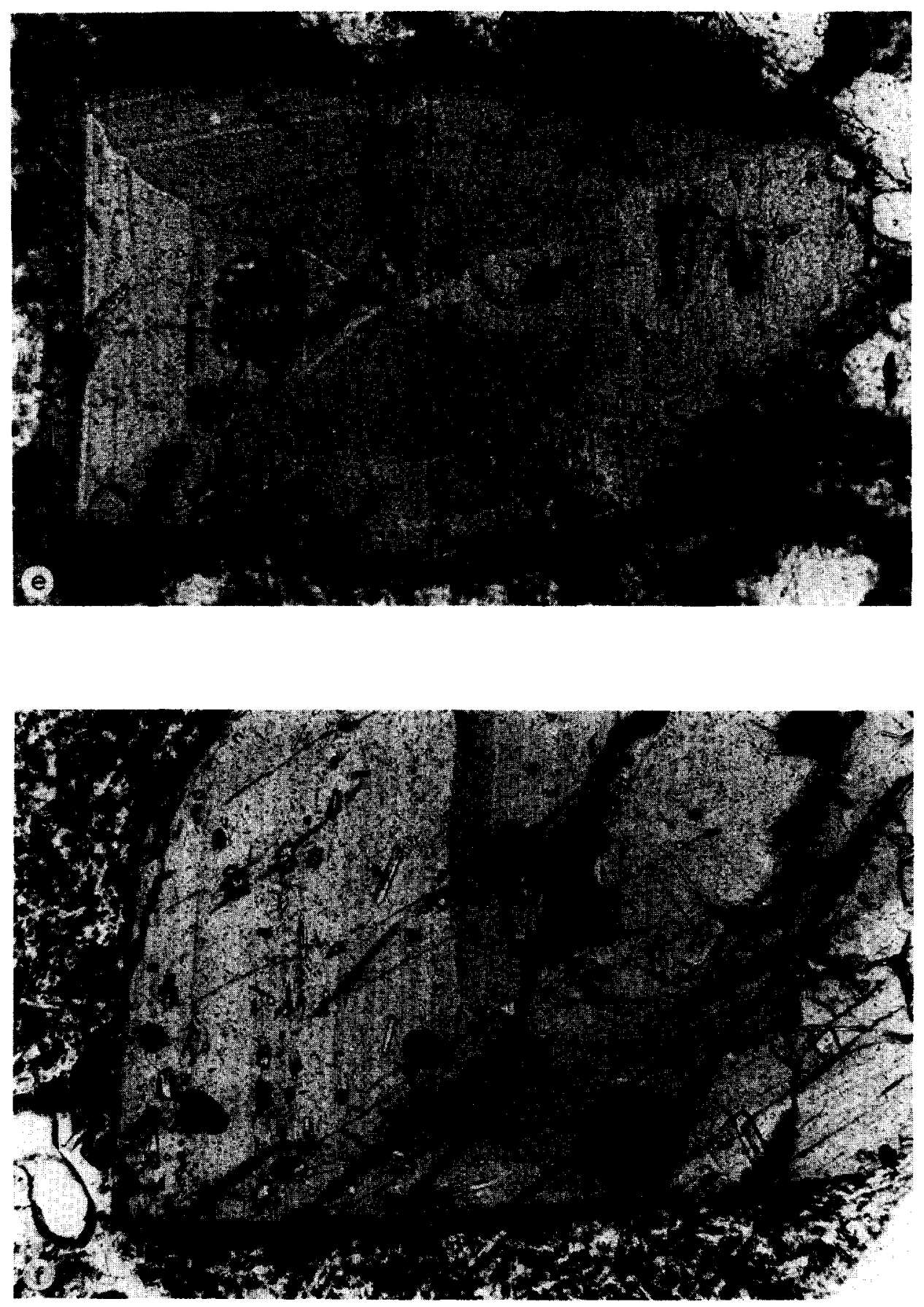

Fig. 5e. Type III phenocryst in TL 977 showing oscillatory and sector zoning. Width of field $1 \mathrm{~mm}$. f. Phenocryst in LP 612 showing oscillatory zoning. Width of field $1.6 \mathrm{~mm}$. 


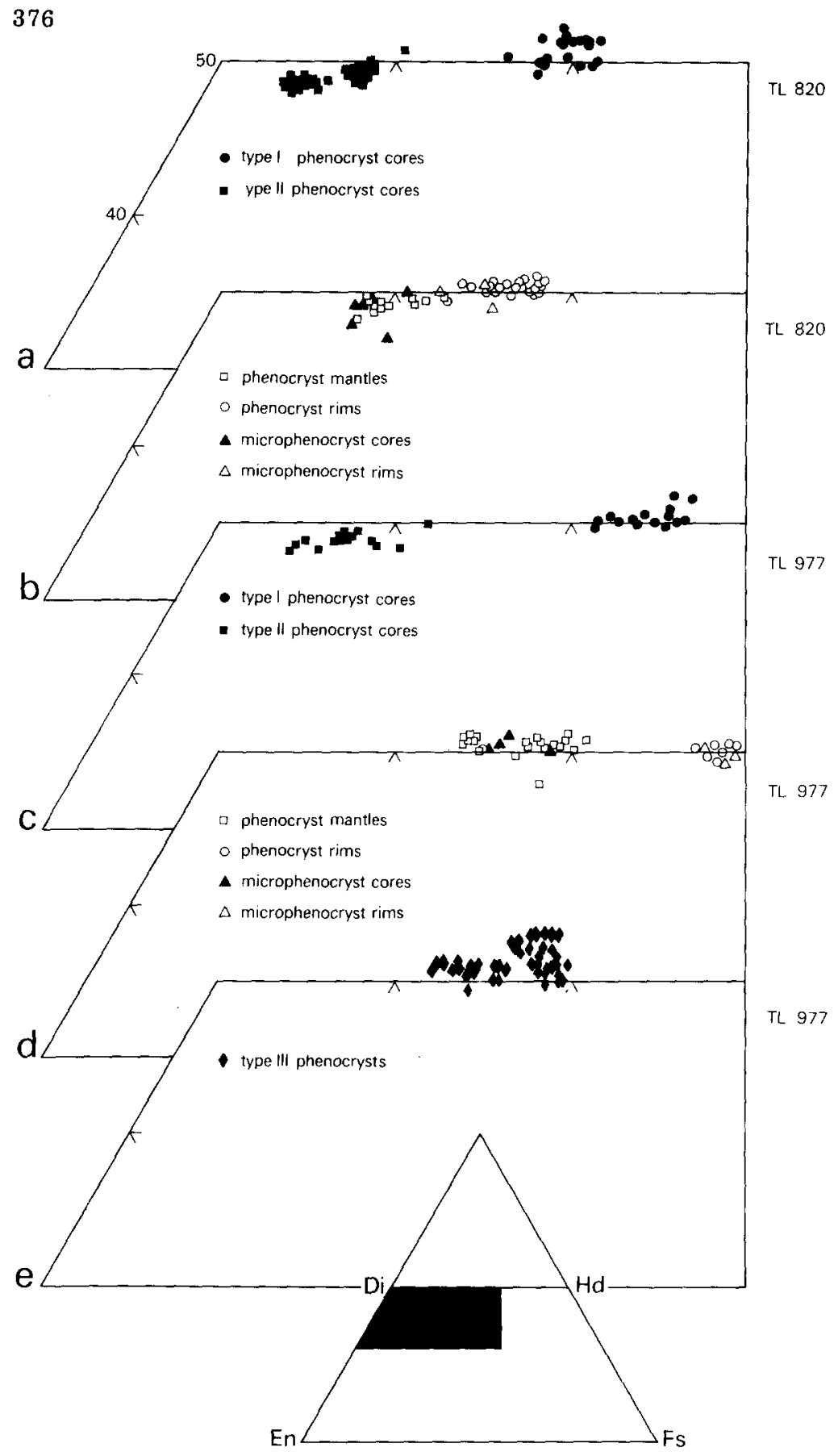

Fig. 6. Clinopyroxenes from the tephritic leucitites plotted in the conventional $\mathrm{Ca}-\mathrm{Mg}$ $\mathrm{Fe}+\mathrm{Mn}$ diagram. a. Cores of Type I and Type II phenocrysts in TL 820 . b. Mantles of Type I and Type II phenocrysts, cores of microphenocrysts and rims of phenocrysts and microphenocrysts in TL 820 . c. Cores of Type I and Type II phenocrysts in TL 977. d. Mantles of Type I and Type II phenocrysts, cores of microphenocrysts and rims of phenocrysts and microphenocrysts in TL 977. e. Type III phenocrysts in TL 977. 
The microphenocrysts and groundmass pyroxenes in the tephritic leucitites are noteworthy because: (a) the cores of the microphenocrysts are identical in appearance to the mantles of the Type I and Type II phenocrysts in the same lava and, in TL 977, to the Type III phenocrysts: and (b) the groundmass pyroxenes are identical in appearance to the rims of all types of phenocryst and to the rims of the microphenocrysts.

The compositions of the pyroxene phenocrysts and microphenocrysts are plotted in Fig. 6. The cores of Type I phenocrysts are salites and are enriched in $\mathrm{Al}, \mathrm{Ti}$ and calculated $\mathrm{Fe}^{2+}$ and $\mathrm{Fe}^{3+}$ compared with the diopsidic cores of Type II phenocrysts (Fig. 6a,c. See also Table IV); Na shows no strong preference for either pyroxene. The mantles of both types of phenocryst overlap in composition with the cores of the microphenocrysts (Fig. 6b,d) and, in the case of TL 977, with the Type III phenocrysts (Fig. 6e), as might be expected from the petrographic observations. Furthermore, the mantles, microphenocryst cores and Type III phenocrysts are intermediate in composition to the salite and diopside cores of Type I and II phenocrysts in the same lava, although some overlap occurs. In particular, there is significant overlap in composition between the diopside cores of Type II phenocrysts, the mantles of Type I phenocrysts and the cores of the microphenocrysts in TL 820 and this is discussed further below.

From inspection of Fig. 6 it is evident that compositional differences exist between the pyroxenes in TL 820 and those in TL 977 . The salite cores of Type I phenocrysts in TL 977 are richer in $\Sigma \mathrm{Fe}^{2+}$ than those in TL 820 , as are the microphenocryst cores. Similarly, the rims of the pyroxene phenocrysts and microphenocrysts in TL 977 are much richer in $\Sigma \mathrm{Fe}^{2+}$ than the rims of the phenocrysts and microphenocrysts in TL 820. These differences undoubtedly reflect the different $\mathrm{Mg} /\left(\mathrm{Mg}+\Sigma \mathrm{Fe}^{2+}\right)$ ratios of the host lavas (Table III).

Microprobe analyses at 5-10 $\mu \mathrm{m}$ intervals across individual phenocrysts indicate that:

(a) The boundaries between core, mantle and rim in Type I and Type II phenocrysts are chemically discontinuous.

(b) Oscillatory zoning involves marked sympathetic variations in $\Sigma \mathrm{Fe}^{2+}$, $\mathrm{Al}$ and $\mathrm{Ti}$ (cf. Thompson, 1972); the maximum variations of these elements (expressed as cations on the basis of 6 oxygens) between adjacent zones are $\Sigma \mathrm{Fe}^{2+} 0.40-0.33, \mathrm{Al} 0.24-0.12$ and Ti $0.03-0.01$. Similar differences were found to exist between the wide, optically distinct bands in some Type III phenocrysts and these bands therefore appear to reflect some sort of oscillatory zoning.

(c) In the one crystal in which sector zoning was studied in detail, the (100) sector is enriched in $\Sigma \mathrm{Fe}^{2+}, \mathrm{Al}$ and Ti relative to the (111) sector, in agreement with the results of Hollister and Gancarz (1971) and Thompson (1977). The maximum differences in these three elements between the two sectors is $\Sigma \mathrm{Fe}^{2+} 0.32-0.23, \mathrm{Al} 0.50-0.23$ and $\mathrm{Ti} 0.06-0.02$ atoms per formula unit.

(d) Concentric zoning is slight but in most cases is normal inasmuch as $\Sigma \mathrm{Fe}^{2+}, \mathrm{Al}$ and $\mathrm{Ti}$ increase towards the rim of the crystal. Thus it is apparent 
that in TL 820 the outer margins of the diopside cores of Type II phenocrysts overlap in composition with the mantles of Type I phenocrysts and with the cores of the microphenocrysts (see above). The importance of this observation will become apparent in the discussion on the origin of the pyroxenes. The diopside cores of Type II phenocrysts in TL 977 show reversed zoning but the mantles show normal zoning.

\section{Zoning of pyroxenes in the leucite phonolites}

The pyroxene phenocrysts in the leucite phonolites are euhedral-anhedral, medium-green, pleochroic (pale green-yellow green-grass green) and show oscillatory, sector and concentric zoning (Fig. 5f). They usually contain inclusions of magnetite. In terms of composition, these pyroxenes are salites

\section{TABLE VI}

Representative analyses and formulae of pyroxenes in the leucite phonolites and the trachyte

\begin{tabular}{|c|c|c|c|c|c|c|}
\hline Sample No. & $\begin{array}{l}612 / 1 \\
\text { core }\end{array}$ & $\begin{array}{l}612 / 1 \\
\mathrm{rim}\end{array}$ & $\begin{array}{l}612 / 2 \\
\text { core }\end{array}$ & $\begin{array}{l}612 / 2 \\
\text { rim }\end{array}$ & $\begin{array}{l}423 / 3 \\
\text { core }\end{array}$ & $\begin{array}{l}423 / 3 \\
\mathrm{rim}\end{array}$ \\
\hline $\mathrm{SiO}_{2}$ & 45.5 & 46.3 & 44.2 & 48.4 & 46.8 & 47.0 \\
\hline $\mathrm{TiO}_{2}$ & 1.71 & 1.28 & 1.89 & 0.92 & 1.25 & 1.20 \\
\hline $\mathrm{Al}_{2} \mathrm{O}_{3}$ & 7.62 & 7.03 & 7.63 & 4.78 & 5.45 & 5.42 \\
\hline${ }^{a} \mathrm{FeO}$ & 10.4 & 9.92 & 11.8 & 10.0 & 11.3 & 10.9 \\
\hline $\mathrm{MnO}$ & 0.40 & 0.41 & 0.47 & 0.47 & 0.39 & 0.47 \\
\hline $\mathrm{MgO}$ & 11.1 & 11.7 & 9.88 & 11.9 & 11.0 & 10.8 \\
\hline $\mathrm{CaO}$ & 23.2 & 23.2 & 22.6 & 22.9 & 23.0 & 22.7 \\
\hline $\mathrm{Na}_{2} \mathrm{O}$ & 0.53 & 0.83 & 0.82 & 0.89 & 0.87 & 0.80 \\
\hline Total & 100.5 & 100.7 & 99.3 & 100.3 & 100.1 & 99.3 \\
\hline${ }^{b} \mathrm{FeO}$ & 3.59 & 1.70 & 3.72 & 3.57 & 3.60 & 4.77 \\
\hline${ }^{b} \mathrm{Fe}_{2} \mathrm{O}_{3}$ & 7.57 & 9.13 & 8.98 & 7.15 & 8.56 & 6.81 \\
\hline $\mathrm{Si}$ & 1.697 & 1.713 & 1.677 & 1.801 & 1.755 & 1.777 \\
\hline $\mathrm{Al}$ & 0.335 & 0.307 & 0.341 & 0.210 & 0.241 & 0.242 \\
\hline $\mathrm{Ti}$ & 0.048 & 0.036 & 0.054 & 0.026 & 0.035 & 0.034 \\
\hline${ }^{b} \mathrm{Fe}^{3+}$ & 0.212 & 0.254 & 0.257 & 0.200 & 0.242 & 0.194 \\
\hline${ }^{b} \mathrm{Fe}^{2+}$ & 0.112 & 0.053 & 0.118 & 0.111 & 0.113 & 0.151 \\
\hline $\mathrm{Mn}$ & 0.013 & 0.013 & 0.015 & 0.015 & 0.012 & 0.015 \\
\hline $\mathrm{Mg}$ & 0.617 & 0.645 & 0.559 & 0.660 & 0.615 & 0.609 \\
\hline $\mathrm{Ca}$ & 0.927 & 0.920 & 0.919 & 0.913 & 0.924 & 0.920 \\
\hline $\mathrm{Na}$ & 0.038 & 0.060 & 0.060 & 0.064 & 0.063 & 0.059 \\
\hline${ }^{\mathrm{a}} \mathrm{Mg}$ & \multirow[b]{2}{*}{0.656} & \multirow[b]{2}{*}{0.678} & \multirow[b]{2}{*}{0.599} & \multirow[b]{2}{*}{0.680} & \multirow[b]{2}{*}{0.632} & \multirow[b]{2}{*}{0.638} \\
\hline$\overline{\left(\mathrm{Mg}+\Sigma \mathrm{Fe}^{2+}\right)}$ & & & & & & \\
\hline${ }^{\mathbf{b}_{\mathbf{M g}}}$ & \multirow{2}{*}{0.846} & \multirow{2}{*}{0.924} & \multirow{2}{*}{0.826} & \multirow{2}{*}{0.856} & \multirow{2}{*}{0.845} & \multirow[b]{2}{*}{0.801} \\
\hline$\overline{\left(\mathrm{Mg}+\overline{\mathrm{Fe}^{2+}}\right)}$ & & & & & & \\
\hline
\end{tabular}

*Below limit of detection. ${ }^{2}$ Total iron as $\mathrm{FeO}$ or $\mathrm{Fe}^{2+}$. ${ }^{\mathrm{b}}$ Calculated assuming $\Sigma$ cations $=$ 4 on the basis of 6 oxygen atoms. 
which show a restricted range of composition (Table VI; Fig. 3b). They are poorer in Al than the salite cores of Type I phenocrysts in the tephritic leucitites though they have similar contents of $\mathrm{Ti}$ and $\Sigma \mathrm{Fe}^{2+}$. Oscillatory zoning in the pyroxene phenocrysts of the leucite phonolites differs from that described above only insofar as the maximum differences in $\Sigma \mathrm{Fe}^{2+}$ $(0.42-0.36), \mathrm{Al}(0.24-0.19)$ and $\mathrm{Ti}(0.04-0.03)$ between adjacent zones are less than those found for the tephritic leucitite pyroxenes. Sector zoning was studied in detail in only one crystal in which the $(010)$ sector is enriched in $\Sigma \mathrm{Fe}^{2+}, \mathrm{Al}, \mathrm{Ti}$ and, possibly, $\mathrm{Na}$ relative to the (111) sector in accordance with the results of Hollister and Gancarz (1971). The pyroxenes in both leucite phonolites show slight, reversed, concentric zoning, i.e., $\Sigma \mathrm{Fe}^{2+}, \mathrm{Al}$ and Ti decrease towards the rims of the crystals (Table VI).

\begin{tabular}{cccccc}
\hline $\begin{array}{l}423 / 1 \\
\text { core }\end{array}$ & $\begin{array}{l}423 / 1 \\
\text { rim }\end{array}$ & $\begin{array}{l}885 / 4 \\
\text { core }\end{array}$ & $\begin{array}{l}885 / 4 \\
\text { rim }\end{array}$ & $\begin{array}{l}885 / 12 \\
\text { core }\end{array}$ & $\begin{array}{l}885 / 12 \\
\text { rim }\end{array}$ \\
\hline 45.5 & 46.7 & 50.3 & 50.6 & 48.7 & 51.0 \\
1.70 & 1.19 & 0.22 & 0.43 & 0.81 & 0.34 \\
6.91 & 5.57 & 1.66 & 1.96 & 5.39 & 2.20 \\
13.1 & 11.5 & 13.4 & 15.4 & 9.34 & 12.3 \\
0.49 & 0.39 & 0.67 & 0.69 & 0.22 & 0.62 \\
9.44 & 10.8 & 10.6 & 11.2 & 12.8 & 12.5 \\
23.2 & 22.9 & 22.3 & 19.5 & 22.4 & 21.7 \\
0.62 & 0.77 & 0.76 & 0.43 & $*$ & 0.54 \\
\hline 101.0 & 99.8 & 99.9 & 100.2 & 99.7 & 101.2 \\
6.03 & 4.37 & 8.68 & 13.3 & 7.23 & 8.09 \\
7.86 & 7.92 & 5.24 & 2.38 & 2.35 & 4.68 \\
1.710 & 1.758 & 1.910 & 1.925 & 1.825 & 1.896 \\
0.306 & 0.247 & 0.074 & 0.088 & 0.238 & 0.096 \\
0.048 & 0.034 & 0.006 & 0.012 & 0.023 & 0.010 \\
0.222 & 0.225 & 0.150 & 0.068 & 0.066 & 0.131 \\
0.190 & 0.138 & 0.276 & 0.422 & 0.227 & 0.252 \\
0.016 & 0.012 & 0.022 & 0.022 & 0.007 & 0.020 \\
0.529 & 0.606 & 0.600 & 0.635 & 0.715 & 0.693 \\
0.934 & 0.924 & 0.907 & 0.795 & 0.899 & 0.864 \\
0.045 & 0.056 & 0.056 & 0.032 & - & 0.039 \\
& & & & & \\
0.563 & 0.626 & 0.584 & 0.564 & 0.710 & 0.644 \\
& & & & & \\
0.736 & 0.815 & 0.685 & 0.601 & 0.759 & 0.733 \\
& & & & & \\
\hline
\end{tabular}


This lava contains pale-green pyroxene phenocrysts which are often rimmed by opaque minerals. Only slight concentric zoning was observed. Analyses of phenocryst cores and rims (Table VI) suggest complex zoning patterns; in some crystals $\Sigma \mathrm{Fe}^{2+}, \mathrm{Al}$ and Ti increase from core to rim, but in other crystals this pattern is reversed. With one exception, zoning is not associated with large variations in $\mathrm{Al}$, $\mathrm{Ti}$ or $\mathrm{Mg} /\left(\mathrm{Mg}+\Sigma \mathrm{Fe}^{2+}\right)$, but may be associated with relatively large variations in $\mathrm{Ca}$ (Fig. 3c) though, as in the case of $\Sigma \mathrm{Fe}^{2+}, \mathrm{Al}$ and $\mathrm{Ti}$, this element shows no consistent behaviour between core and rim. Because the pyroxene phenocrysts are often rimmed by opaques, and may have undergone partial replacement by opaques, it is not clear that compositional variations between the core and rim reflect crystal growth phenomena.

\section{DISCUSSION}

The data presented in the preceding section indicate that: (a) the chemical variation shown by the Type I and Type II phenocrysts in the tephritic leucitites cannot be explained by the processes responsible for oscillatory, sector and concentric zoning; (b) the salite and diopside phenocryst cores cannot have been in equilibrium with the same melt simultaneously; and (c) neither the salite nor the diopside was in equilibrium with the host melt immediately prior to eruption. The composition of the equilibrium pre-eruption pyroxene is represented by the mantles of the Type I and Type II phenocrysts, by the cores of the microphenocrysts and, in TL 977, by the Type III phenocrysts. The groundmass crystals and the rims of the phenocrysts and microphenocrysts grew during eruption and quenching.

Several workers have ascribed the occurrence of salite and diopside cores in the same lava to the effects of pressure, $f_{\mathrm{H}_{2} \mathrm{O}}$ and/or $f_{\mathrm{O}_{2}}$ on the composition of pyroxenes crystallized from alkaline magmas (Babkine et al. 1968; Frisch and Schmincke, 1969; Brotzu et al., 1974, 1977; Scott, 1976; Ghiara and Lirer, 1977). Crystallization at different pressures is an unlikely explanation because Thompson $(1974,1977)$ found that increasing pressure favours increasing $\mathrm{Na}$ and $\mathrm{Al}^{\mathrm{vi}}$ (i.e., jadeite component) in pyroxenes crystallized at or near the liquidus of an Alban Hills leucitite, whereas in the Vulsini tephritic leucitites Na shows no preference for either the diopsides or the salites and the behaviour of $\mathrm{Al}$ in both types of pyroxene can be explained in terms of the same substitutions (Fig. 4a). Furthermore, salites and diopsides occur in all varieties of lava of Phase 4 age in the Bolsena-Orvieto zone, and since these are believed to have evolved at low pressures by gravitycontrolled fractional crystallization processes, it is improbable that either type of pyroxene crystallized at significantly higher pressures than the other.

The effects of $f_{\mathrm{H}_{2} \mathrm{O}}$ and $f_{\mathrm{O}_{2}}$ are difficult to evaluate because of the paucity of relevant experimental data, but it is significant that the range of composition shown by the Type I and Type II phenocrysts in the Vulsini 
tephritic leucitites is considerably greater than that shown by pyroxenes crystallized experimentally from a natural Vesuvius tephritic leucitite with water contents of $0.85-3$ wt\% (Dolfi and Trigila, 1978a,b). It is not clear that $f_{\mathrm{O}_{2}}$ was buffered in these experiments and the compositions of the synthetic pyroxenes may thus reflect the effects of both $f_{\mathrm{H}_{2} \mathrm{O}}$ and $f_{\mathrm{O}_{2}}$. As the water content of the melt increases, its dissociation will cause an increase in $f_{\mathrm{O}_{2}}$; increasing $f_{\mathrm{O}_{2}}$ should raise the $\mathrm{Fe}^{3+} / \mathrm{Fe}^{2+}$ ratio of the melt and increasing $f_{\mathrm{H}_{2} \mathrm{O}} \mathrm{O}$ will decrease the activity of silica in the melt (nb. water causes depolymerization of silicate melts). Reduction of $a_{\mathrm{SiO}_{2}}^{\text {melt }}$ favours incorporation of $\mathrm{Fe}^{3+}, \mathrm{Al}$ and $\mathrm{Ti}$ in coexisting pyroxene due to substitutions such as $\mathrm{M}_{\mathrm{vi}}^{2+}+\mathrm{Si}_{\mathrm{iv}}^{4+} \leftrightharpoons \mathrm{Fe}_{\mathrm{vi}}^{3+}+\mathrm{Al}_{\mathrm{iv}}^{3+}, \mathrm{M}_{\mathrm{vi}}^{2+}+\mathrm{Si}_{\mathrm{iv}}^{4+} \leftrightharpoons \mathrm{Al}_{\mathrm{vi}}^{3+}+\mathrm{Al}_{\mathrm{iv}}^{3+}$ and $\mathrm{M}_{\mathrm{vi}}^{2+}+2 \mathrm{Si}_{\mathrm{iv}}^{4+} \rightleftharpoons \mathrm{Ti}_{\mathrm{vi}}^{4+}+$ $2 \mathrm{Al}_{\mathrm{iv}}^{3+}$ whereas the high $\mathrm{Fe}^{3+} / \mathrm{Fe}^{2+}$ ratio of the melt reduces the amount of $\mathrm{Fe}^{2+}$ available to the pyroxene. The salites are indeed richer in $\mathrm{Fe}^{3+}, \mathrm{Al}$ and $\mathrm{Ti}$ than the diopsides, but they are also richer in $\mathrm{Fe}^{2+}$ (Table IV) indicating crystallization from a melt with a lower $\mathrm{Mg} /\left(\mathrm{Mg}+\mathrm{Fe}^{2+}\right)$ ratio than the one from which the diopsides crystallized. Although melts with appropriate $\mathrm{Mg} /\left(\mathrm{Mg}+\mathrm{Fe}^{2+}\right)$ ratio, $f_{\mathrm{H}_{2}} \mathrm{O}$ and $f_{\mathrm{O}_{2}}$ may be produced during the cooling of tephritic leucitite magma, it is unlikely that the salites crystallize from such magmas at temperatures substantially lower than the diopsides, as this would not explain the resorption of the salites or the occurrence of microphenocrysts with higher $\mathrm{Mg} /\left(\mathrm{Mg}+\mathrm{Fe}^{2+}\right)$ ratios in the same rock. Furthermore, while crystal settling in a zoned magma chamber can explain all of the features of the Type I phenocrysts (cf. Borley et al., 1971), this process cannot account for the resorption of the diopside cores in TL 977 , the absence of phenocryst cores with compositions intermediate to the diopsides and salites, and the mantling of the diopside cores by pyroxene with a lower $\mathrm{Mg} /\left(\mathrm{Mg}+\mathrm{Fe}^{2+}\right)$ ratio.

Under certain circumstances, precipitation of an oxide phase such as magnetite could lower both the $\mathrm{Fe}^{3+}$ and $\mathrm{Fe}^{2+}$ contents of the melt allowing diopsidic pyroxene to crystallize after salite. There is no evidence that this occurred in the Vulsini tephritic leucitites; on the contrary, petrographic observations indicate simultaneous crystallization of magnetite and salite, but not of magnetite and diopside.

On the basis of the arguments presented above, we conclude that the salite and the diopside cores of Type I and Type II phenocrysts did not crystallize from the same magma. This conclusion is supported by recent Sr-isotope studies which demonstrate that salites and diopsides in potassiumrich lavas from Ernici and Roccamonfina are not in isotopic equilibrium with each other or with the groundmass of the lava in which they occur (Civetta et al., 1981; Vollmer et al., 1981). Probably the simplest interpretation of these data is that the salites and diopsides are xenocrysts which originate by the disaggregation of accidental xenoliths, as has been proposed for salites in some other potassium-rich lavas (Barton and Van Bergen, 1981), but two lines of evidence suggest that this is not so in the case of the lavas under consideration: (a) xenoliths or even other likely xenocrystal phases do not occur in the Phase 4 lavas of the Bolsena-Orvieto zone; and (b) it is improb- 
able that two compositionally distinct types of pyroxene originate by the disaggregation of xenoliths, especially in view of the widespread occurrence of salites and diopsides in alkaline lavas from central and south Italy.

The only plausible explanation for the occurrence of salites and diopsides in the Vulsini tephritic leucitites is that they crystallized from different magmas, the salites from a relatively evolved (Fe-rich) magma and the diopsides from a relatively primitive (Mg-rich) magma, and that these mixed prior to eruption. Some resorption may occur during mixing, because both types of phenocryst are out of equilibrium with the melt. It might be expected that the salites, which come into contact with a hotter magma, would be resorbed to a greater extent than the diopsides and this is borne out by petrographic observations. Resorption of both the salites and the diopsides in TL 977 suggests that pyroxene temporarily ceased crystallizing and this can be explained in terms of the thermal curvature of liquidus surfaces in natural magma systems (Walker et al., 1979). That the diopside cores in TL 820 show little evidence of resorption could indicate that the composition of the hybrid magma was close to that of the Mg-rich end member involved in the mixing process, and evidence in support of this is noted below. As thermal and chemical equilibrium are re-established after mixing, a pyroxene of intermediate composition may crystallize from the hybrid melt and in the case of the Vulsini tephritic leucitites this is represented by the mantles around the salite and diopside cores, by the microphenocrysts and by the Type III phenocrysts. This implies that complete homogenization of the melt has taken place, which has not been established in previous studies of potassium rich lavas for which a magma mixing origin has been proposed. However, the features shown by the Type I and Type II phenocrysts described in this study are similar to those shown by olivine, pyroxene and plagioclase phenocrysts in some basalts and calc alkaline lavas which are likewise interpreted in terms of magma mixing (Dungan and Rhodes, 1978; Rhodes et al., 1979; Sakuyama, 1979; Luhr and Carmichael, 1980).

There is no evidence that either strongly evolved (nb. absence of feldspar phenocrysts, differing $\mathrm{Al}$ contents of the salite cores and the pyroxene phenocrysts in the leucite phonolites) or strongly mafic ( $\mathrm{nb}$. absence of olivine phenocrysts) melts were involved in the mixing process, and we suggest that mixing took place between two batches of tephritic leucitite magma. The following observations are consistent with this suggestion: (a) the microphenocrysts and Type III phenocrysts in TL 977 are similar in composition to the salite phenocryst cores; and (b) the microphenocrysts in TL 820 are similar in composition to the diopside phenocryst cores, i.e., the pyroxenes precipitated from hybrid tephritic leucitites have similar compositions to the pyroxene phenocrysts in the magmas involved in the mixing process. As noted previously, this may explain the lack of resorbtion of the diopside phenocryst cores in TL 820 .

Other Vulsini HKS lavas contain phenocryst assemblages which show evidence of disequilibrium with the host melt (Varekamp, 1979). This evi- 
dence includes: the occurrence of anhedral, embayed leucites, the presence of sanidine xenocrysts in leucitites and tephritic leucitites, and the occurrence in various lavas of plagioclase, apatite and magnetite xenocrysts which are resorbed or, in the case of plagioclase, show discontinuous zoning. Furthermore, calculations using the plagioclase-liquid (Kudo and Weill, 1970; Mathez, 1973) or olivine-liquid (Roeder and Emslie, 1970) geothermometers often yield temperatures which are unacceptably high or low, and silica activities of the melts, calculated using appropriate mineral assemblages, are in many cases unrealistic for silica-undersaturated lavas (Varekamp, 1979). Hence we suggest that magma mixing may be fairly common in the Vulsini HK series. It may be added that the leucite phonolites (LP 612, LP 423) contain strongly resorbed leucites and plagioclase phenocrysts with discontinuous zoning and could represent hybrid magmas even though the compositions and zoning patterns of the pyroxenes provide no evidence for this.

The complex core-rim relationships shown by the pyroxenes in the LKS trachyte are not simply explicable in terms of normal crystal-liquid equilibria, and may also reflect magma mixing, although more detailed studies are required to evaluate this possibility. Nevertheless, it is noteworthy that Brotzu et al. (1974) have described pyroxenes from a Vulsini trachyte which show comparable features to the pyroxenes in the tephritic leucitites, e.g., with an anhedral core surrounded by a lighter coloured rim. Furthermore, some LKS lavas from Vulsini contain mantled feldspars which, following Hibbard (1981), may reflect the mixing of two magmas.

The occurrence of resorbed leucite xenocrysts in some LKS lavas (Varekamp, 1979) is suggestive that mixing, possibly on a limited scale, has occurred between LKS and HKS magmas at Vulsini. Although this evidence is tenuous, it is entirely consistent with the cyclic nature of volcanic activity in this district.

O'Hara (1977) predicted that simultaneous magma mixing and fractional crystallization would lead to anomalous enrichment of the strongly compatible and the strongly incompatible trace elements compared with fractional crystallization alone. This prediction has been confirmed in the case of certain MORB and calc alkaline suites by Rhodes et al. (1979), Shibata et al. (1979) and Luhr and Carmichael (1980) and can be tested for the Vulsini lavas using the results of least-squares modelling techniques for the major elements and the concentration of Th in the lavas. For example, Varekamp (1979) has shown that leucite phonolite can be derived from leucite tephrite by removal of $11 \%$ clinopyroxene, $13.5 \%$ plagioclase, $0.4 \%$ apatite and $5.1 \% \mathrm{Fe}$-ore. The maximum possible enrichment of a strongly incompatible element in the leucite phonolite can be calculated from the Rayleigh fractionation equation by assuming $D=0$, and is found to be 1.43. The actual enrichment factor for Th is 2.27 , suggesting that the concentrations of the strongly incompatible elements in the leucite phonolites cannot be due to fractional crystallization alone. The result of this calculation lends 
support to the conclusion that magma mixing has been important at Vulsini, but it must be borne in mind that other processes, which could also result in anomalous trace-element concentrations, such as combined assimilation and fractional crystallization (Taylor et al., 1979; De Paolo, 1981) may also have affected these magmas.

\section{CONCLUSIONS AND IMPLICATIONS}

A detailed study of pyroxene phenocrysts in tephritic leucitites from Vulsini leads to the conclusion that magma mixing was an important process in the evolution of these lavas. It is suggested that mixing took place between a relatively primitive (Mg-rich) tephritic leucitite and a more evolved (Fe-rich) tephritic leucitite magma. Petrographic and chemical data indicate that many of the Vulsini lavas represent hybrid magmas and that mixing may also have occurred between HKS and LKS magmas in this district. It seems likely that magmas resided in shallow reservoirs, where differentiation occurred, throughout much of the volcanic history of Vulsini. Periods of tensional tectonics and subsidence allowed the uprise of primitive potassic magma (Varekamp, 1980,1981 ) which in some cases mixed thoroughly with the more evolved magmas in the reservoirs and subsequently the hybrid magmas were erupted as lava flows. In other cases, injection of hot, primitive magma into reservoirs containing highly evolved, lower density HKS or LKS magmas may have triggered explosive eruptions of the latter (cf. Sparks et al., 1977; Sigurdsson and Sparks, 1981) thus accounting for the relatively large proportion of pyroclastic material erupted at Vulsini.

Petrological studies (Thompson, 1977; Civetta et al., 1979; this paper) and geochemical studies (Cortini and Hermes, 1981; Vollmer et al., 1981) suggest that magma mixing may have occurred at many of the central and southern Italian volcanic centres, and this possibility should be taken into account in future studies of the potassium-rich lavas in this region. In particular, the possible effects of magma mixing and other processes, e.g., assimilation, should be quantitatively evaluated before attempts are made to characterize the source regions of the original magmas using trace element data. It is - hus essential that petrographic and mineralogical studies are integrated with geochemical studies, and that fractionation models based upon major element least-squares modelling are tested using trace element data.

Although we believe that the ultimate source of potassium-rich magmas lies in the upper mantle, and that this source may possess unusual geochemical characteristics (Hawkesworth and Vollmer, 1979; Vollmer and Hawkesworth, 1980; Cortini and Hermes, 1981), it is worth pointing out that unambiguously primary magmas have not, to date, been identified amongst the erupted HKS lavas of western Italy; $\mathrm{Mg} /\left(\mathrm{Mg}+\Sigma \mathrm{Fe}^{2+}\right)$ ratios of non-cumulate lavas from Vulsini, Vico, Sabatini, the Alban Hills, Ernici, Roccamonfina and SommaVesuvius are $<0.69$, the minimum value predicted for liquids in equilibrium with upper mantle olivine $\left(\mathrm{Fo}_{88-92}\right)$ from the relationship given by Roeder 
and Emslie (1970) for the partitioning of $\mathrm{Mg}$ and $\mathrm{Fe}$ between olivine and melt. The absence of primary, erupted liquid compositions could be due to two factors: (a) the primary melts fractionally crystallize at high pressures or en route to the surface (Appleton, 1972) or (b) the primary magmas are intercepted by, and mix with, more evolved magmas in the magma chambers underlying the western Italian volcanoes, as has been invoked to explain the absence or rarity of erupted, primary MORB and calc alkaline magmas (Sparks et al., 1980; Stolper and Walker, 1980; Luhr and Carmichael, 1981). Further studies may show which of these two processes is most important.

\section{ACKNOWLEDGEMENTS}

The first named author is indebted to Professors J. Zussman and W.S. MacKenzie for permission to use the electron microprobe in the Department of Geology, University of Manchester and to T. Hopkins and D. Plant for advice and help with the microprobe analyses. We also wish to thank P. Anten for the whole-rock chemical analyses, I.M. Santoe for drafting the figures, E.C.M. Daniels for typing the manuscript, J.P.P. Huijsmans and V.J.M. Salters for discussion of this work and I.A. Nicholls for a critical review of an earlier version of this manuscript.

\section{REFERENCES}

Anderson, A.T., 1976. Magma mixing: petrological process and volcanological tool. J. Volcanol. Geotherm. Res., 1: 3-33.

Appleton, J.D., 1972. Petrogenesis of potassium-rich lavas from the Roccamonfina volcano, Roman Region, Italy. J. Petrol., 13: 425-456.

Babkine, J., Conquéré, F. and Vilminot, J.-C., 1968. Les caractères particuliers du volcanisme au nord de Montpellier: l'absarokite du Pauget; la ferrisalite sodique de Grabels. Bull. Soc. Fr. Minéral. Cristallogr., 91: 141-150.

Barberi, F. and Leoni, L., 1980. Metamorphic carbonate ejecta from Vesuvius plinian eruptions: evidence of the occurrence of shallow magma chambers. Bull. Volcanol., 43: $107-120$.

Barbieri, M., Penta, A. and Turi, B., 1975. Oxygen and strontium isotope ratios in some ejecta from the Alban Hills volcanic area, Roman comagmatic region. Contrib. Mineral. Petrol., 51: 127-133.

Barton, M., 1979. A comparative study of some minerals occurring in the potassiumrich alkaline rocks of the Leucite Hills, Wyoming, the Vico volcano, western Italy, and the Toro-Ankole region, Uganda. Neues Jahrb. Mineral. Abh., 137: 113-134.

Barton, M. and Van Bergen, M.J., 1981. Green clinopyroxenes and associated phases in a potassium-rich lava from the Leucite Hills, Wyoming. Contrib. Mineral. Petrol., 77: $101-114$.

Borley, G.D., Suddaby, P. and Scott, P., 1971. Some xenoliths from the alkalic rocks of Teneriffe, Canary Islands. Contrib. Mineral. Petrol., 31: 102-114.

Brooks, C.K. and Printzlau, I., 1978. Magma mixing in mafic alkaline volcanic rocks: the evidence from relict phenocryst phases and other inclusions. J. Volcanol. Geotherm. Res., 4: 315-331. 
Brotzu, P., Morbidelli, L. and Traversa, G., 1973. Lave e prodotti scoriacei del settore di Monterado (Bolsena-Vulsini orientali): studio geo-petrografico. Boll. Serv. Geol. Ital., 94: 353-404.

Brotzu, P., Morbidelli, L. and Traversa, G., 1974. Significato petrologica delle variazioni composizionali caratterizzanti i fenocristalli clinopirossenici delle lave alcalinopotassiche nel settore di Monterado (Vulsini orientali). Mem. Inst. Geol. Mineral. Univ. Padova, 31: 1-18.

Brotzu, P., Morbidelli, L. and Traversa, G., 1977. Clinopirossini del Monterado. Mem. Geol. Soc. Ital., 16: 2-18.

Civetta, L., Innocenti, F., Lirer, L., Manetti, P., Munno, R., Peccerillo, A., Poli, G. and Serri, G., 1979. Serie potassica ed al ta in potassio dei Monti Ernici (Lazio Meridionale): considerazioni petrografiche e geochimiche. Rend. Soc. Ital. Mineral. Petrol., 35: 227-249.

Civetta, L., Innocenti, F., Manetti, P., Peccerillo, A. and Poli, G., 1981. Geochemical characteristics of potassic volcanics from Mts. Ernici (Southern Latium, Italy). Contrib. Mineral. Petrol., 78: 37-47.

Cortini, M. and Hermes, O.D., 1981: Sr isotopic evidence for a multi-source origin of the potassic magmas in the Neapolitan area (S. Italy). Contrib. Mineral. Petrol., 77 : $47-55$.

Cundari, A., 1975. Mineral chemistry and petrogenetic aspects of the Vico lavas, Roman volcanic region, Italy. Contrib. Mineral. Petrol., 53: 129-144.

Cundari, A., 1979. Petrogenesis of leucite-bearing lavas in the Roman volcanic region, Italy: the Sabatini lavas. Contrib. Mineral. Petrol., 70: 9-21.

Cundari, A. and Le Maitre, R.W., 1970. On the petrogeny of the leucite-bearing rocks of the Roman and Birunga volcanic regions. J. Petrol., 11: 33-47.

Cundari, A. and Mattias, P.P., 1974. Evolution of the Vico lavas, Roman volcanic region, Italy. Bull. Volcanol., 38: 98-114.

DePaolo, D.J., 1981. Trace element and isotopic effects of combined wallrock assimilation and fractional crystallization. Earth Planet. Sci. Lett., 53: 189-202.

Dolfi, D. and Trigila, R., 1978a. Clinopyroxenes from potassic lavas of central Italy Quaternary volcanism. Nat. Environ. Res. Counc. Publ. Ser. D, 11: 18-22.

Dolfi, D. and Trigila, R., 1978b. The role of water in the 1944 Vesuvius eruption. Contrib. Mineral. Petrol., 67: 297-304.

Donaldson, C.H. and Brown, R.W., 1977. Refractory megacrysts and magnesium-rich melt inclusions within spinel in oceanic tholeiites: indicators of magma mixing and parental magma-composition. Earth Planet. Sci. Lett., 37: 81-89.

Dungan, M.A. and Rhodes, J.M., 1978. Residual glasses and melt inclusions in basalts from DSDP legs 45 and 46: evidence for magma mixing. Contrib. Mineral. Petrol., 67: 417-431.

Eichelberger, J.C., 1975. Origin of andesite and dacite: evidence of mixing at Glass Mountain in California and at other circum-Pacific volcanoes. Geol. Soc. Am. Bull., 86: $1381-1391$.

Frisch, T. and Schmincke, H.-U., 1969. Petrology of clinopyroxene-amphibole inclusions from the Roque Nublo volcanics, Gran Canaria, Canary Islands (Petrology of the Roque Nublo Volcanics I). Bull. Volcanol., 33: 1073-1088.

Ghiara, M.R. and Lirer, L., 1977. Mineralogy and geochemistry of the "low potassium" series of the Roccamonfina volcanic suite (Campania, South Italy). Bull. Volcanol., 40: 39-56.

Hawkesworth, C.J. and Vollmer, R., 1979. Crustal contamination versus enriched mantle: ${ }^{143} \mathrm{Nd} /{ }^{144} \mathrm{Nd}$ and ${ }^{77} \mathrm{Sr} /{ }^{86} \mathrm{Sr}$ evidence from the Italian volcanics. Contrib. Mineral. Petrol., 69: 151-165.

Hibbard, M.J., 1981. The magma mixing origin of mantled feldspars. Contrib. Mineral. Petrol., 76: 158-170. 
Hollister, L.S. and Gancarz, A.J., 1971. Compositional sector-zoning in clinopyroxene from the Narce area, Italy. Am. Mineral., 56: 959-979.

Kudo, A.M. and Weill, D.F., 1970. An igneous plagioclase thermometer. Contrib. Mineral. Petrol., 25: 52-65.

Luhr, J.F. and Carmichael, I.S.E., 1980. The Colima volcanic complex, Mexico. I. Postcaldera andesites from Volcán Colima. Contrib. Mineral. Petrol., 71: 343-372.

Luhr, J.F. and Carmichael, I.S.E., 1981. The Colima volcanic complex, Mexico. Part II. Late-Quaternary cinder cones. Contrib. Mineral. Petrol., 76: 127-147.

Mathez, E.A., 1973. Refinement of the Kudo-Weill plagioclase thermometer and its application to basaltic rocks. Contrib. Mineral. Petrol., 41:61-72.

O'Hara, M.J., 1977. Geochemical evolution during fractional crystallization of a periodically refilled magma chamber. Nature, 266: 503-507.

Rahman, S., 1975. Some aluminous clinopyroxenes from Vesuvius and Monte Somma, Italy. Mineral. Mag., 40:43-52.

Rhodes, J.M., Dungan, M.A., Blanchard, D.P. and Long, P.E., 1979. Magma mixing at mid-ocean ridges: evidence from basalts drilled near $22^{\circ} \mathrm{N}$ on the Mid-Atlantic ridge. Tectonophysics, 55: 35-61.

Roeder, P.L. and Emslie, R.F., 1970. Olivine-liquid equilibrium. Contrib. Mineral Petrol., 29: 275-289.

Sakuyama, M., 1979. Evidence of magma mixing: petrological study of Shirouma-Oike calc-alkaline andesite volcano, Japan. J. Volcanol. Geotherm. Res., 5: 179-208.

Savelli, C., 1967. The problem of rock assimilation by Somma-Vesuvius magma. I. Composition of Somma and Vesuvius lavas. Contrib. Mineral. Petrol., 16: 328-353.

Scott, P.W., 1976. Crystallization trends of pyroxenes from the alkaline volcanic rocks of Tenerife, Canary Islands. Mineral. Mag., 40: 805-816.

Shibata, T., DeLong, S.E. and Walker, D., 1979. Abyssal tholeiites from the Oceanographer Fracture Zone. I. Petrology and fractionation. Contrib. Mineral. Petrol., 70: 89-102.

Sigurdsson, H. and Sparks, R.S.J., 1981. Petrology of rhyolitic and mixed magma ejecta from the 1875 eruption of Askja, Iceland. J. Petrol., 22: 41-84.

Sparks, R.S.J., Sigurdsson, H. and Wilson, L., 1977. Magma mixing: a mech anism for triggering acid explosive eruptions. Nature, 267: 315-318.

Sparks, R.S.J., Meyer, P. and Sigurdsson, H., 1980. Density variation amongst mid-ocean ridge basalts: implications for magma mixing and the scarcity of primitive lavas. Earth Planet. Sci. Lett., 46: 419-430.

Stolper, E. and Walker, D., 1980. Melt density and the average composition of basalt. Contrib. Mineral. Petrol., 74: 7-12.

Taylor, H.P., Jr., Giannetti, B. and Turi, B., 1979. Oxygen isotope geochemistry of the potassic igneous rocks from the Roccamonfina volcano, Roman comagmatic region, Italy. Earth Planet. Sci. Lett., 46: 81-106.

Thompson, R.N., 1972. Oscillatory and sector zoning in augite from a Vesuvian lava. Carnegie Inst. Washington Yearb., 71: 463-470.

Thompson, R.N., 1974. Some high-pressure pyroxenes. Mineral. Mag., 39: 768-787.

Thompson, R.N., 1977. Primary basalts and magma genesis. III. Alban Hills, Roman comagmatic province, Central Italy. Contrib. Mineral. Petrol., 60: 91-108.

Trigila, R., 1969. Sulla genesi dei magmi a carattere mediterraneo. Periodico Mineral., 38: 625-660.

Turi, B., and Taylor, H.P. Jr., 1976. Oxygen isotope studies of potassic volcanic rocks of the Roman Province, Central Italy. Contrib. Mineral. Petrol., 55: 1-31.

Varekamp, J.C., 1979. Geology and Petrology of the Vulsinian Volcanic Area (Latium, Italy). Ph.D. Dissertation, State University of Utrecht, Utrecht, 384 pp.

Varekamp, J.C., 1980. The geology of the Vulsinian area, Lazio, Italy. Bull. Volcanol., 43: $487-503$. 
Varekamp, J.C., 1981. Relations between tectonics and volcanism in the Roman Province, Italy. In: S. Self and R.S.J. Sparks (Editors), Tephra Studies. D. Reidel Publishing Company, Dordrecht (Holland), pp. 219-225.

Vollmer, R. and Hawkesworth, C.J., 1980. Lead isotopic composition of the potassic rocks from Roccamonfina (South Italy). Earth Planet. Sci. Lett., 47: 91-101.

Vollmer, R., Johnston, K., Ghiara, M.R., Lirer, L. and Munno, R., 1981. Sr isotope geochemistry of megacrysts from continental rift and converging plate margin alkaline volcanism in south Italy. J. Volcanol. Geotherm. Res., 11: 317-327.

Walker, D., Shibata, T. and DeLong, S.E., 1979. Abyssal tholeiites from the Oceanographer Fracture Zone. II. Phase equilibria and mixing. Contrib. Mineral. Petrol., 70: $111-125$. 